\title{
A comparison of North American shale plays with emerging non- marine shale plays in Australia
}

P.N.K. De Silva ${ }^{1, *}$, S.J.R. Simons ${ }^{1}$, P. Stevens ${ }^{2}$ and L.M.Philip ${ }^{1}$

${ }^{1}$ International Energy Policy Institute, UCL Australia, University College London, 220

Victoria Square, Adelaide 5000, Australia; n.desilva@ucl.ac.uk ;+61 881109991

${ }^{2}$ Royal Institute of International Affairs, Chatham House, 10 St James's Square London.

\section{Abstract}

Geological and petrophysical parameters are critical in evaluating the production potential of prospective shale gas plays and their economic viability for commercial development. However, based on the US experience, these characteristics can vary widely. Furthermore, the non-marine shale plays of the Cooper Basin, South Australia are distinctively different from the marine shale plays in the US. Non-marine shale may consist of higher clay content and, thus, may be less responsive to hydraulic fracturing due to the increased ductility. Conversely, the availability of sufficient amounts of quartz and siderite may counteract this effect and maintain brittleness. In this study, the mineral, total organic and gas content, thermal maturity, Poisson's ratio and Young's modulus data obtained from the Roseneath and Murteree formations of the Cooper Basin have been compared with US shale formations. The results show that the formations compare well in terms of thickness, thermal maturity, Young's modulus and Poisson's ratio, but not in clay mineral content and formation temperature and values for TOC, porosity and gas-in-place are comparatively lower. To determine whether such plays are economically viable will require technical, as well as 
economic, analysis of the hydraulic fracturing process, including the potential for horizontal and vertical well development or basin centred gas developments. A shale play that has unfavourable prospects may have upfront infrastructure and major capital costs that outweigh the potential receipts from gas production.

Keywords: Petrophysical, Sedimentology, Brittleness, Shale gas 


\subsection{Introduction}

Globally, there is widespread interest in exploiting shale gas resources to meet rising energy demands, maintain energy security and stability in supply and reduce dependence on higher carbon sources of energy, namely coal and oil (ACOLA, 2013; EY, 2013; Johnson and Boersma, 2013; Rogers, 2011). However, extracting shale gas is a resource intensive process and is dependent on the geological and petrophysical characteristics of the source rocks, making the development of certain formations uneconomic using current technologies. Therefore, evaluation of the in situ properties of shale formations, together with technological advancements, is critical in verifying the economic viability of such formations (Weijermars, 2013). Although studies have been conducted mainly on US marine shales, there are substantial deposits of non-marine shale formations in China and Australia (Chou, 2013; Zou et al., 2010). Currently, the responsiveness to hydraulic fracturing of non-marine shales compared to US marine shales is not clear (Tang et al., 2014). This paper provides an evaluation of non-marine shale gas development potential using well testing data from the Cooper basin, South Australia.

\subsection{Significance of shale gas}

In Australia, current conventional gas production is predominantly based on the offshore resources, with onshore resources becoming severely depleted (Figure 1) (Stevens et al., 2013). Liquid hydrocarbon resources are not substantial enough to provide security of supply and independence from imports from an increasingly unstable Middle East, and coal is falling out of favour due to its high carbon emissions and other environmental impacts (Jaramillo et al., 2007; Leather et al., 2013; Stevens, 2014). Therefore, there is an increasing interest in unconventional natural gas resources, as gas is a relatively cleaner fuel compared to coal and 
these resources appear to be widespread in many regions of the country (Govt, 2012; Leather et al., 2013). Similar situations exist in other parts of the world (KPMG, 2011). Furthermore, the US experience has shown that production costs of unconventional natural gas can be lower in comparison to other fossil fuel resources (Stevens, 2012).

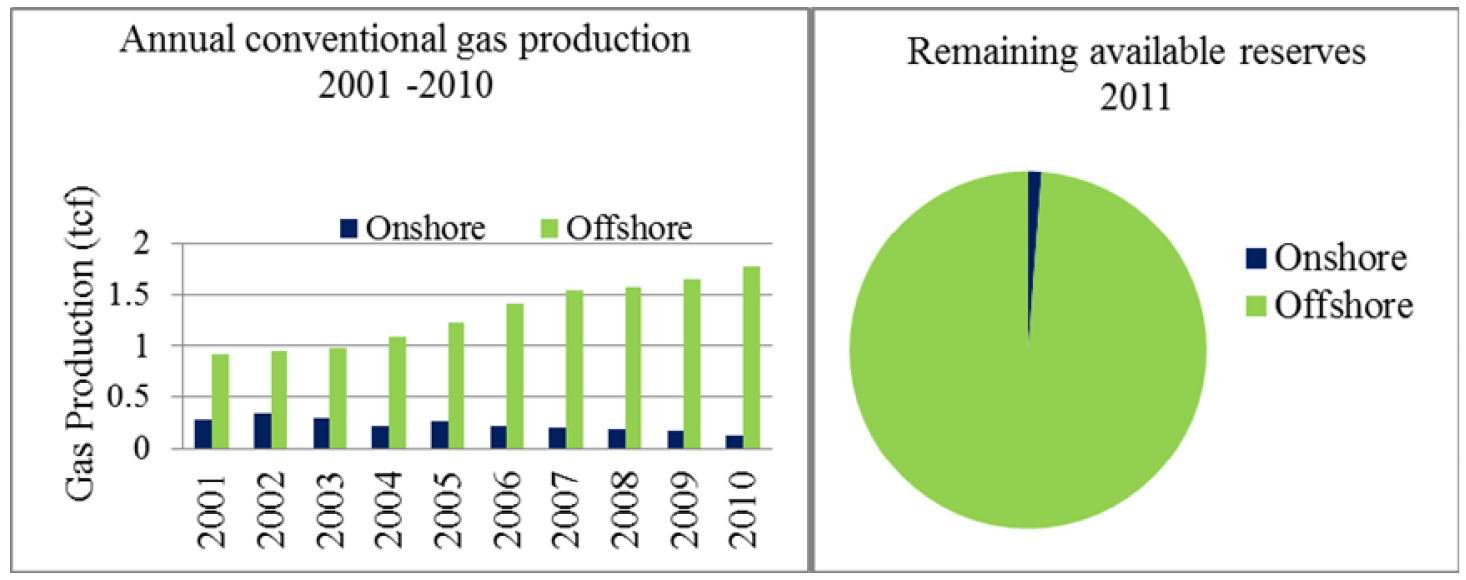

Figure 1. Conventional Australian gas production and remaining reserves (Australia, 2010; Stevens et al., 2013)

Globally, technically recoverable shale gas reserves are estimated to be around 25,300 Tcf (more than 45\% in the US) (Boyer et al., 2011; Stark et al., 2012). Already in the US, natural gas prices have decreased steadily compared to oil and coal, as illustrated in Figure 2. This is mainly due to the shale gas boom driving down the cost of natural gas production. The US is already planning to export this excess amount of natural gas to maintain the stability of natural gas markets(Ker, 2013). This unconventional natural gas revolution is leading the US towards energy independence, with shale gas predicted to contribute a greater than $50 \%$ share of natural gas production by 2040, as illustrated in Figure 3. However, it is not yet certain whether the US shale gas success story can be replicated elsewhere. This is mainly due to differences in shale geology, as most of the formations in the US are marine in origin, which naturally consist of low clay contents, enabling the permeability of the reservoir to be 
increased effectively by hydraulic fracturing (Cardott, 2012). In addition, other factors, such as the availability of infrastructure, a high gas price, a vibrant service industry, favourable regulations and private mineral rights, have also contributed to the US shale gas boom (Stevens et al., 2013).

Whether greenhouse gas emissions from shale gas production are comparable to those from the conventional gas production is still open to debate (Burnham et al., 2011; Howarth et al., 2011; O'Sullivan and Paltsev, 2012) and the issue remains one of concern. However, natural gas driven power stations produce $50 \%$ less greenhouse gas emissions compared to coal fired power stations producing similar energy content (OGP, 2012) and by switching to gas, the US has been projected to reach its carbon abatement targets(C2ES, 2013). Furthermore, shale gas production consumes less water than coal extraction (Jenner and Lamadrid, 2013).

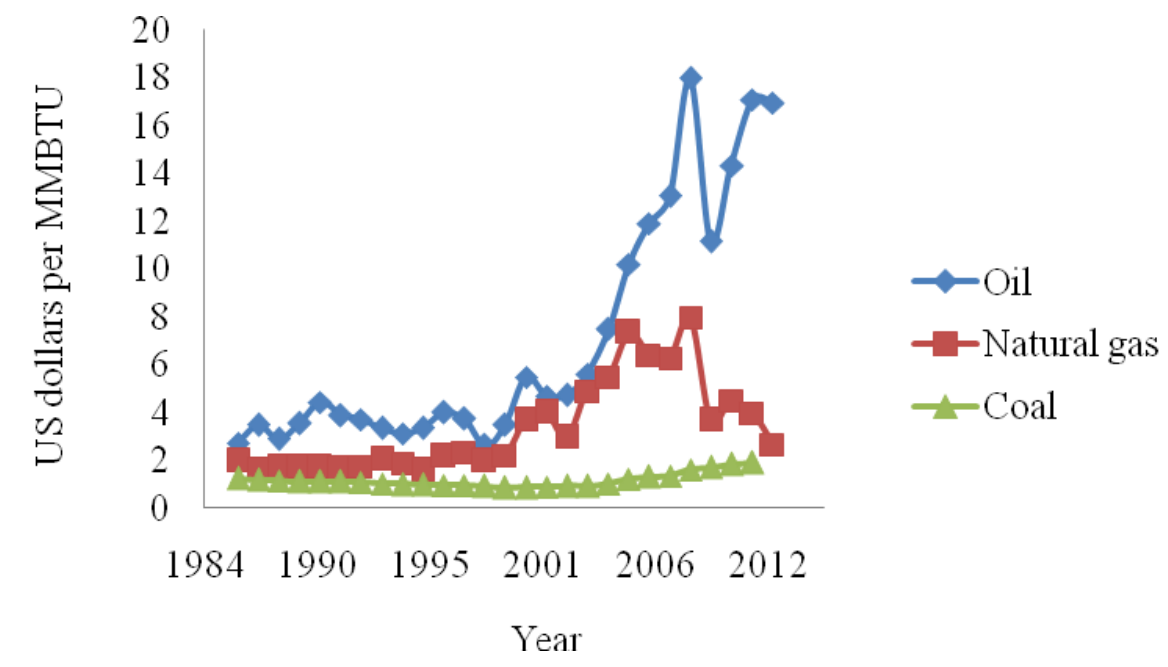

Figure 2. Price comparison of oil, natural gas and coal (EIA, 2015) 


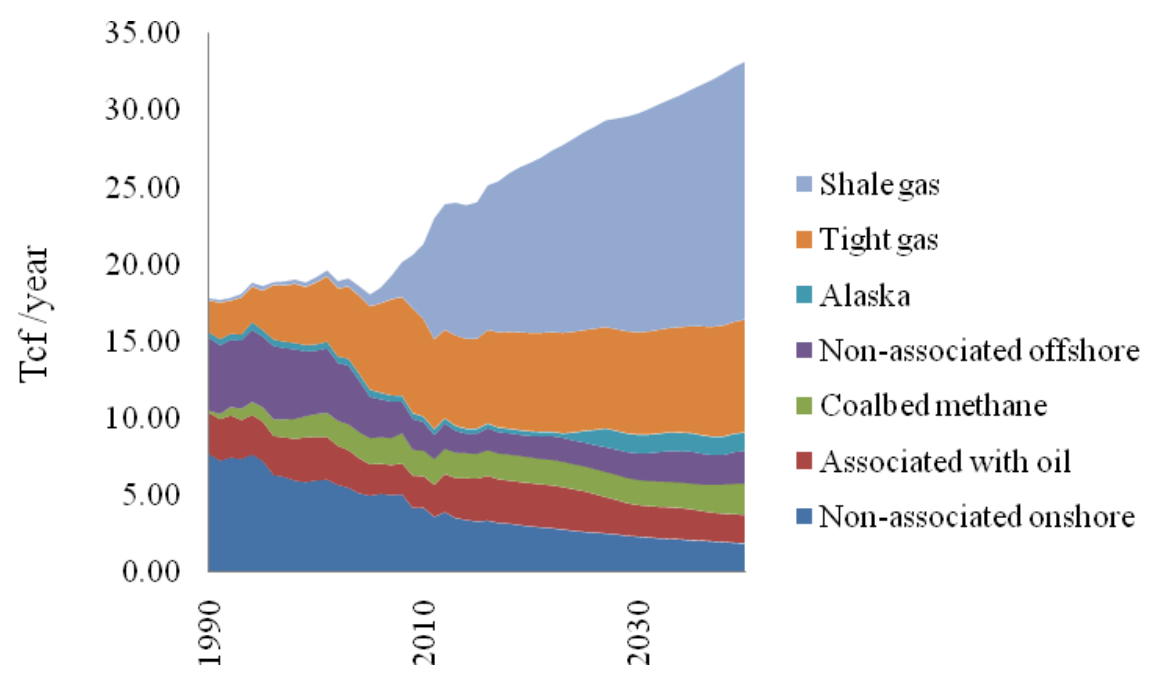

Figure 3. Projected increase of shale gas use in US (EIA, 2014)

\subsection{Shale sedimentology}

Shale formations have the potential to generate hydrocarbons and store them within low permeable networks. In the shale network, gas generation can be either biogenic or thermogenic. Biogenic gas generally forms at depths less than $1000 \mathrm{~m}$, but can be preserved in reservoirs at depths as large as 4500m (Deshpande, 2008). During diagenesis, shales undergo recrystallization, compaction, cementation, and lithification. These processes contribute to the dual functionality of shale reservoirs as source and storage reservoirs, with low porosity and permeability.

Shale formations can be broadly classified as either marine or lacustrine in origin. Marine shales originate from deep coastal sedimentation systems, whilst lacustrine shale systems originate from deep lake-based inland environmental systems. By inception, marine shale has a higher quartz content compared to lacustrine shale, and lacustrine shales usually have higher clay contents. 


\subsection{The Nature of Shale Formations}

\subsection{US Shale Formations}

All commercially operating US shale plays are of marine type (Figure 4) (Boyer et al., 2011). Marine shales are composed of marine mudrocks, which are best described as depositions in muddy coastlines, near shore, mid-shelf mudbelts, open-shelf mud blankets, basinal slopes and basinal floors (Pashin et al., 2011). These can consist of higher quartz content, increasing the brittleness characteristics of the shale formation. In the following sections, major US shale formations are described.

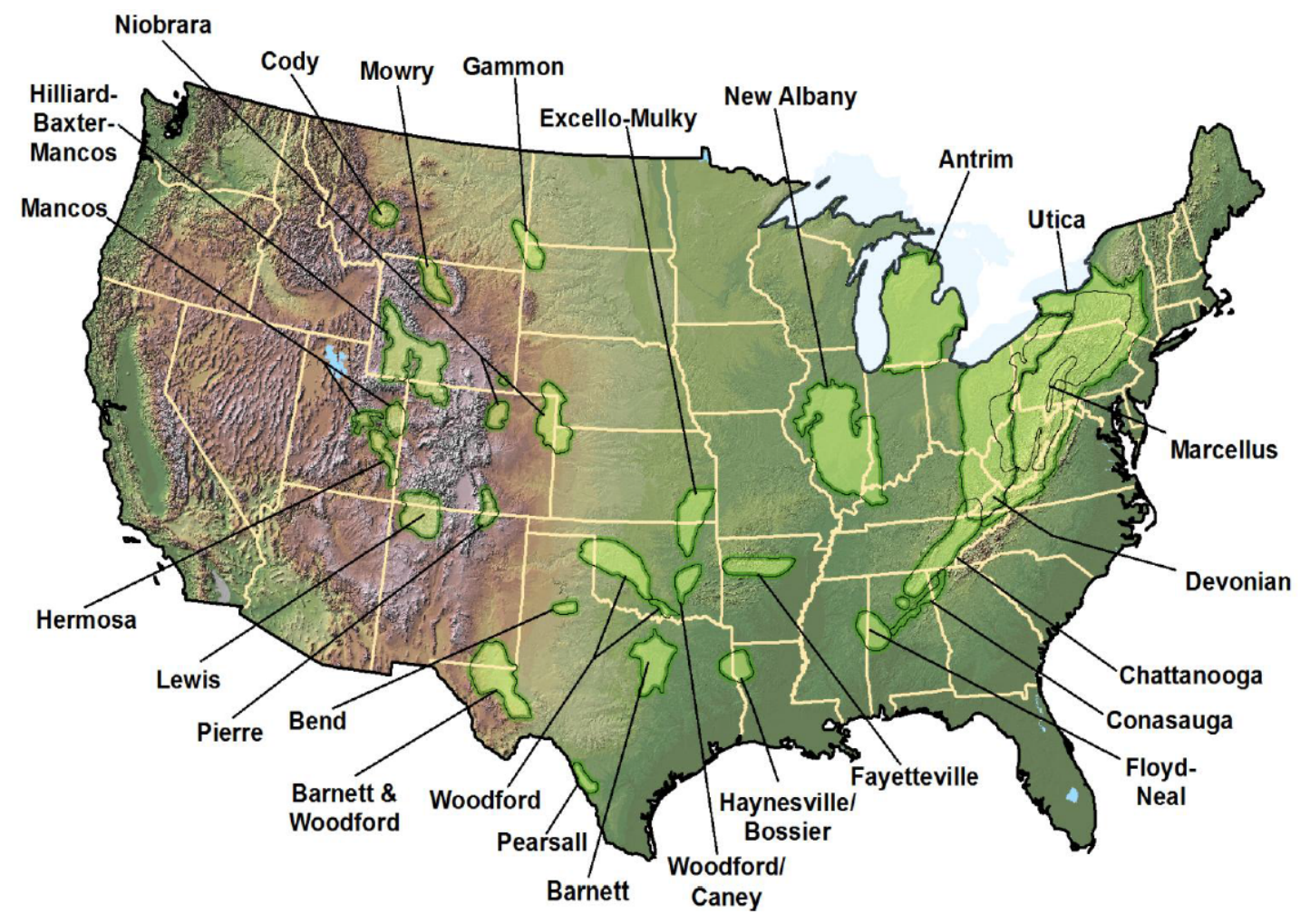

Figure 4. US shale formations (USDOE, 2009) 
i) Marcellus shale:

Marcellus shale is a Devonian age (more than 370 million years) shale play, located in Pennsylvania (Transform, 2011), with an estimated gas resource of around 410Tcf,as of 2009 (EIA, 2011). This is the most successful basin, primarily responsible for the shale gas revolution in the US. However, in the current context focus has shifted towards shale oil resources due to the higher economic gains (Stevens, 2012). The Marcellus shale is an organic rich black shale also consisting of limestone, carbonates and pyrite (Haluszczak et al., 2013). These black shales are extremely rich in hydrocarbon content with higher organic contents (i.e. liquids).

ii)Haynesville shale

Haynesville shaleis greyish black to blackish green colour andconsists of siliceous mudstone, laminated calcareous mudstone and calcareous bioturnated mudstone(Schulz and Horsfield, 2010). There is around 75Tcf of gas resource available, as of 2009 (EIA, 2011).The formation was deposited around 150-160 million years ago (late Jurassic) (Transform, 2011). A majority of the developed gas is of thermogenic type due to the deeper depth (Agarawal, 2009). This characteristic is common to Australian shales.

iii) Barnett shale

The Barnett shale consists of multiple lithologies such as the laminated argillaceous lime mudstones, laminated siliceous mudstones, carbonate concretions and skeletal argillaceous lime packstones (Day-Stirrat et al., 2008), deposited during the Mississippian age (over 320 345 million years ago) (Day-Stirrat et al., 2008). However, Barnett shale is not a black shale, but it is an organic-rich, siliceous shale with variable amounts of limestone, dolomite, and 
minerals (Schulz and Horsfield, 2010). Barnett and Barnett-Woodford shales have combined reserves of 76Tcf, as of 2009 (EIA, 2011).

\section{iv) Eagleford shale}

In the Eagleford shale, there are21Tcf of shale gas and 3 billion barrels of oil resources (EIA, 2011). This shale formation was deposited over 70-100 million years ago (Transform, 2011) and is much younger than the gas-rich Marcellus shale. The Eagleford shale formation is a dark, well-laminated shale, thinly interstratified, consisting of limestones and carbonaceous quartzose siltstones(Dawson, 2000).

iv) Fayetteville shale

The Fayetteville shale is located in the Arkoma Basin of northern Arkansas. In Fayetteville shale, there is about 32Tcf of shale gas resource (EIA, 2011). This shale formation was deposited during the Mississippian age (330 - 360 million years ago)and contains limestone and sandstone(Bai et al., 2013; Transform, 2011; USGS, 2014).It consists of black, organicrich rock ranging in depths of 500-2000m.

\subsection{Cooper Basin of South Australia}

The Cooper Basin extends from northern South Australia into South-Western Queensland, covering about $130,000 \mathrm{~km}^{2}$ (Figure 5). It is one of the largest Australian Gondwanan intracratonic basins, containing about $2.5 \mathrm{~km}$ non-marine strata, including prospective Permian-age shales (Hill 2010). Permian Murteree and Roseneath shales formed from the depositions of siltstones and mudstones in large lakes and are the main shale gas targets in the Cooper Basin. These formations have a maximum thickness of up to $85-105 \mathrm{~m}$ which is an adequate prerequisite for a shale gas play. There are four major depocentres, namely, the 
Patchwara, Tenppera, Arrabury and Nappameri troughs(DMITRE, 2012a), containing a thick (1600m) Permian to Triassic succession of lacustrine, deltaic, fluvial and glacial rocks at the base. The predominance of carbonaceous and silty shales and coals within the Permian succession also make this region a potential target for basin-centered tight gas and coal seam gas (ACOLA, 2013). In the Nappamerri trough, most of the gas is generated by the organic rich coal seams that may have migrated through the section.

The Cooper Basin has a history of more than 50 years of natural gas development. However, only about 15 shale gas wells have been drilled and completed in the Cooper Basin so far, compared with about 20 shale wells per day in the US. However, compared to other identified shale basins in Australia, the Cooper Basin is the most viable, with processing plant, roads and pipeline infrastructure already existing to some extent. Currently, there are more than 2000 gas wells with more than 5Tcf of historical development(Dello, 2014; DMITRE, 2013). The success of these operations suggests that the Cooper Basin will have a high potential for shale gas development, migrated gas being present in basin-centered plays at various depths. There are an estimated $85 \mathrm{Tcf}$ of technically recoverable shale gas resources in place (EIA, 2011). 


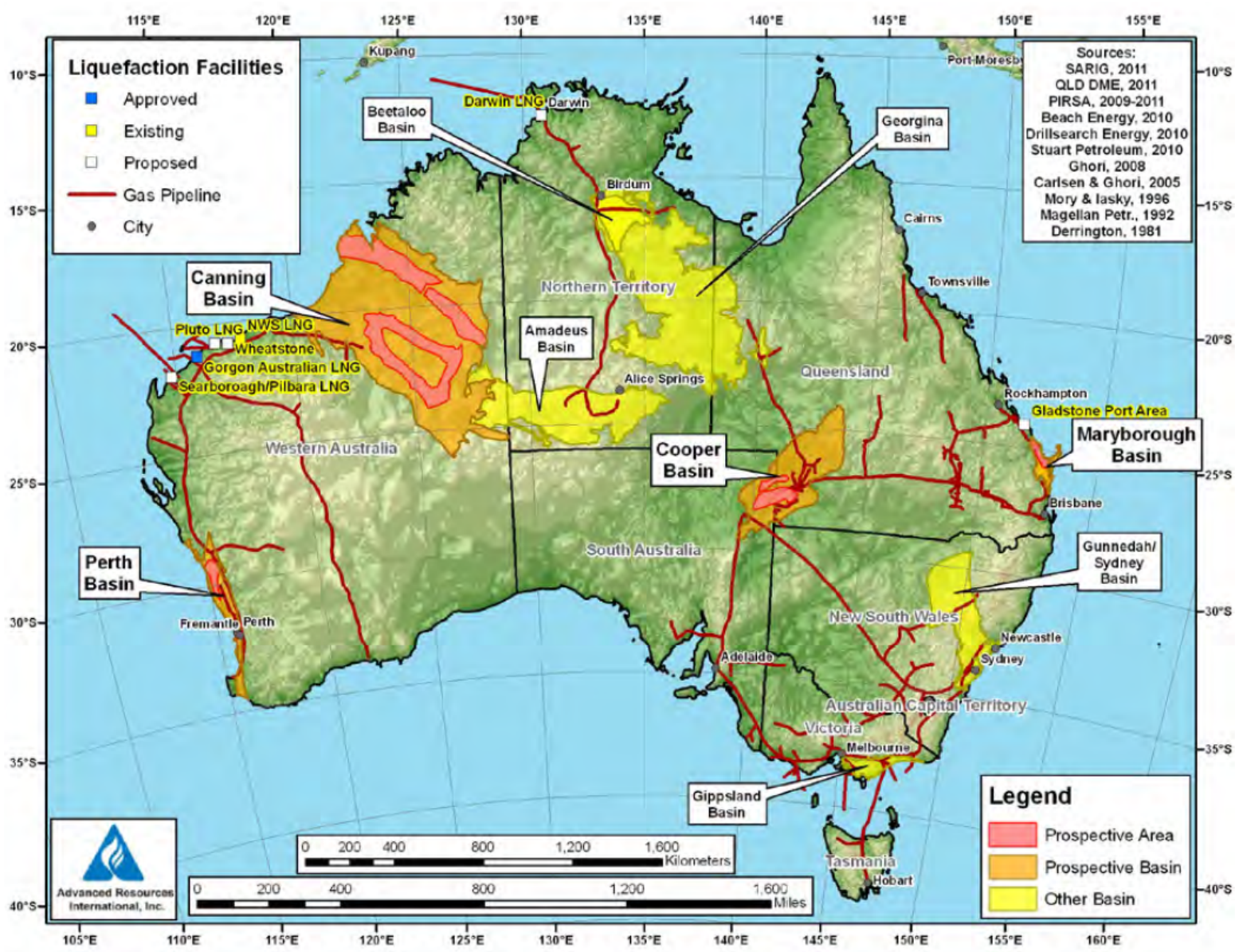

Figure 5. Australian shale gas basins (EIA, 2013)

\subsection{Petro physical parameters}

The key petrophysical parameters are total organic matter (TOC), thermal maturity, thickness, water saturation, porosity and kerogen (insoluble organic matter) type. Productive shale gas formations have been found to be those with thicknesses greater than $65 \mathrm{~m}$ (for a horizontal shale well), containing greater than $3 \%$ TOC, hydrogen index values of greater than $350 \mathrm{mg} \mathrm{HC} / \mathrm{g}$, thermal maturities of more than $1.1 \%$ (vitrinite reflectance) and containing type II kerogen (Slatt and Rodriguez, 2012). Other studies have specified the 
importance of depth, appropriate mineral contents, reservoir pressure conditions and porosity (Zou, 2013). Additionally, carbon dioxide $\left(\mathrm{CO}_{2}\right)$, clay and water contents are also important in verifying the resource richness. The following sections describe these important parameters.

\subsection{Total organic content (TOC)}

This is one of the critical parameters in determining the resource richness of a shale reservoir. Organic-rich shale consists of significant amounts of gas trapped within fractures and micropores and adsorbed onto organic matter. Therefore, the TOC usually has a linear correlation with the gas content of a formation (Zhang et al., 2012) and the quality of the source rock can be classified based on this number, identified using the shale lithofacies (rock records)(Wang and Carr, 2012). Hence, the TOC is an important parameter in understanding the shale gas content that can be recovered, although it is not a direct estimation of hydrocarbon potential and other parameters have also to be considered (Bai et al., 2013). However, rocks with a TOC content of more than $10 \%$ are usually thermally immature for development (Alexander et al., 2011; Nicolas et al., 2010). Mature shale formations have a TOC range of 2-10\% (Alexander et al., 2011).

\subsection{Thermal maturity}

Thermal maturity is a function of burial history of the formation. It is measured by light reflected off vitrinite maceral at 500X magnification in oil (Averitt, 1975). In well log data analysis, it can be estimated using the log indices of resistivity and density-neutron separation values. The average of these values in well-defined geologically correlative areas is used to compare core vitrinite reflectance data. Kerogen exposed to progressively higher temperatures overtime leads to increased vitrinite reflectance. Gas saturation level increases 
with thermal maturity (Zhao et al., 2007). Vitrinite reflectance values ranging from 0.6 $1.1 \%$ correspond to oil and wet gas contents of less than $0.6 \%$, indicating immature kerogen content (Alexander et al., 2011). A vitrinite reflectance level of between1.1\% - 3.0 \%indicates a good potential for gas development (Huang et al., 2012; Jarvie, 2012).

\subsection{Porosity}

Shale porosity can be determined in terms of the organic and inorganic content. Organic porosity is dependent on the thermal maturity; the lower the thermal maturity, the lower the organic porosity (Curtis et al., 2012). Inorganic porosity is vital for the storage and production of hydrocarbons. Typically, shale porosity is estimated by using methodologies such as the helium gas expansion, mercury injection capillary pressure and log analysis (Clarkson et al., 2011). Pore diameter is typically in the order of nanometres (Kuila and Prasad, 2013). Shale is a dual porosity medium, with gas stored as free gas in macro pores and mesopores $(>2 \mathrm{~nm})$ and as adsorbed gas in nanopores $(<2 \mathrm{~nm})$. Open natural fractures can potentially hold substantial volumes of free gas (Lee et al., 2011). However, the presence of such fractures diffuses the energy associated with the hydraulic fracturing process and, thus, may actually inhibit natural gas production (Gale et al., 2007; Montgomery et al., 2005; Nelson et al., 2007). Previous studies have proposed correction factors to compensate for the many subsurface variables that modify porosity of shale gas systems (Bust et al., 2013; Glorioso and Rattia, 2012; Hartman et al., 2011). However, in the exploration and appraisal phase of resource exploitation, a multitude of corrections is often untenable, since the data requirement is large. This would overly complicate the petrophysical characterisation process. In this study, density logs were used to estimate porosity using Equation 1(Asquith and Gibson, 1982). The neutron log and sonic logs were not used because they are too greatly affected by clay bound water and by the presence of natural gas (Beach Energy, 2015). 


$$
\emptyset=\frac{\rho_{m}-\rho_{b}}{\rho_{m}-\rho_{f}}
$$

Equation 1

Where, $\rho_{m}$ is the rock matrix density $\left(\mathrm{g} / \mathrm{cm}^{3}\right), \rho_{b}$ is the bulk density of the rock $\left(\mathrm{g} / \mathrm{cm}^{3}\right)$ and $\rho_{f}$ is the gas fluid density $\left(\mathrm{g} / \mathrm{cm}^{3}\right)$.

\subsection{Permeability}

A reservoir with a permeability of less than $0.1 \mathrm{~nm}^{2}$ is referred to as "unconventional"(Boyer et al., 2011). Permeability is a function of hydrocarbon saturation, mineralogy and porosity (Alexander et al., 2011) and is mainly dependent on the effective stress, anisotropy, pore size, porosity and lithology (Pathi, 2008; Voltolini et al., 2009). The potential to extract gas is limited by the inherently low permeability of the source rock (Curtis, 2002). Permeability is also an important parameter when deciding between horizontal and vertical wells, as horizontal wells are not always economic; where possible, hydraulic fracturing should be targeted at zones with higher permeability, as this will increase the gas production from the well.

The permeability levels of the reservoir rock must be studied carefully to understand the effect of permeability loss due to production. It has been observed, for instance, that shale gas production can be lowered by 20 - 30 times due to reductions in permeability caused by water imbibition and swelling of the clay content. This reduction in permeability is difficult to verify experimentally, but is critical to the determination of production potential and costs, particularly for non-marine shales. Steady-state methods of estimation cannot be used due to the heterogeneity of the pores (Metwally and Sondergeld, 2011). 
There are two types of permeability due to the dual porosity of the shale formations; namely, the matrix and fracture permeability. Both are critical in terms of the gas that could be recovered. Matrix permeability governs the flow of gas from fractures to the well head and ranges typically from between $10^{-4}$ to $10^{-8} \mathrm{~nm}^{2}$ (Lewis et al., 2004). Fracture permeability is dependent on the initial surface roughness and is directly proportional to fracture offset (misaligned fracture faces) (Kassis, 2011). The estimation of permeability using log based methodologies is not as accurate as other direct field-based methodologies, such as the Mini Frac or Rate Transient analysis (Clarkson, 2013). Mini Frac analysis involves the use of controlled well injection to estimate the stress changes and permeability by creating a fracture that propagates towards the wellbore (Arop, 2013). Rate transient analysis refers to the advanced analysis of both production rates and flowing pressures to estimate permeability and stress regimes (Clarkson, 2013). Therefore, these methodologies are more representative of the reservoir properties compared to the empirical, log based methods. Due to the absence of the necessary datasets, analysis of the permeability was not carried out in this study.

\subsection{Water Saturation}

Water saturation can be measured from core extraction, log analysis and capillary pressure analysis (Handwerger et al., 2012). From wireline logs, the water saturation is derived based on the measurements of the electrical properties of the rock. Several methods for the derivation of water saturation have been developed on the basis of the Archie's equation (Alimoradi et al., 2011). However, characteristics such as high maturity make the application of Archie's equation untenable (Bust et al., 2013). In clay rich formations, methods such as Simandoux, Dual Water, Waxman Smits, Juhasz, and Indonesian are commonly applied 
(Peeters, 2011). In this study, the Indonesian equation is used to estimate the irreducible water saturation.

Indonesian: $S_{w}^{n}=\left[\frac{1}{\left(R_{t}\right)\left[\frac{V_{c l}^{1-0.5\left(V_{c l}\right)}}{\sqrt{R_{c l}}}+\left(\frac{0,8 m c}{a_{1} R_{W}}\right)^{0.5}\right]}\right]$

Equation 2

Where, $n$ is the saturation exponent, $a$ is the tortuosity factor, $m$ is the cementation exponent

e is Euler's constant, $R_{t}$ is the true formation resistivity $(\Omega \mathrm{m}), R_{w}$ is the formation water resistivity $(\Omega \mathrm{m}), \mathrm{R}_{\mathrm{cl}}$ is the resistivity of clay $(\Omega \mathrm{m}), \mathrm{V}_{\mathrm{cl}}$ is the total volume of clay $\left(\mathrm{cm}^{3}\right)$.

The constants $a, m$ and $n$ should be derived from laboratory investigations based on samples of rock. The value of $a$ varies with rock type and the tortuosity of the fluid path; typical values range between 0.62-2.45 for conventional reservoirs (Asquith and Gibson, 1982). Alimoradi et al (2011) report that $m$ varies between 1.6 and 2.4, but is typically 2.0. Asquith and Gibson (1982) report that $n$ varies between 1.8 and 2.5, but is usually 2.0. However, for unconventional reservoirs, the ranges of these parameters are less certain.

\subsection{Poisson's ratio and Young's modulus}

Rock strength properties are important to understand the brittleness of the rock. These properties reflect the fracturing potential and are therefore used to identify suitable locations for drilling and completion of production wells. The rock brittleness reflects the combined effect of both Poisson's ratio and Young's modulus (Rickman et al., 2009). Low Poisson's ratio and higher Young's modulus will lead to higher brittleness. Poisson ratios less than 0.25 and Young's modulus higher than $5 \mathrm{GPa}$ have been suggested as the threshold levels appropriate for a prospective shale gas play (Perez and Marfurt, 2013). 


\subsection{Clay content}

The clay content has to be less than $40 \%$ for a successful shale play(DMITRE, 2012b; Mckeon, 2011).However, evaluation criteria in China refer to clay contents less than $30 \%$ (Zou, 2013). Increasing clay content leads to increasing ductility of shale, which is beneficial in terms of forming a better seal to trap the gas within the reservoir, but not in terms of hydraulic fracturing, as the shale will tend to self-heal. As the hydraulic fluid is injected, the permeability will be further reduced due to clay content as the coherence of the matter is high, leading to a reduction in the extraction potential.

\subsection{Forms of gas storage in shale}

Gas is stored in shale via three types of trapping mechanisms. These are; as adsorbed content in micropores; as dissolved content; and as dissolved gas trapped in fractures and as free gas in mesopores and macropores. The storage in fracture space is minimal and cannot be quantified with certainty. Hence, storage in shale is mostly by sorption and by gas trapped in

pore space, either dissolved or as free gas. However, the allocation between adsorbed and free gas in pore space is not clearly understood. Furthermore, uncertainties also stem from the method used to estimate the gas-in-place. Laboratory estimations of formation porosities are based on helium gas measurements that could lead to underestimates of the sorption potential (Ross and Marc Bustin, 2007).

The sorption capacity refers to the gas stored in micropores. The gas stored in micropores has a high degree of correlation with the TOC content (Zhang et al., 2012). The adsorbed amount of gas is a function of kerogen content, pore pressure and temperature (Lewis et al., 2004). However, it has a negative relationship with the mineral content (Wang et al., 2013). The sorption content also depends on the maturity of the formation (Wang et al., 2013). However, 
the sorption content of shale is less than that of coal, due to the lower carbon content and higher mineral content of shale (Chareonsuppanimit et al., 2012). Sorption capacity also increases with increasing kerogen type (Noble et al., 1997). Experimental sorption on core samples has shown a good relationship with the Langmuir isotherm equation (Zhang et al., 2012).

\subsection{Gas content estimation}

Gas content is more appropriately estimated by using the open-hole logs, rather than using a core analysis method, which is finite and not representative of the reservoir as a whole(Decker et al., 1993). The bulk density log is used to estimate the free gas-in-place. The adsorbed gas content is estimated by using core analysis data.

i) Free gas content

The shale pore space is occupied by water, natural gas and other fluids. In order to estimate the free gas volume using static data, the total unoccupied pore space and gas saturation ${ }^{1}$ have to be considered (equation 8) (Dong et al., 2013; Hartman, 2008):

$$
\mathrm{G}_{\mathrm{f}}=\frac{1000}{\mathrm{p}} \phi \cdot\left(1-\mathrm{S}_{\mathrm{w}}\right) / \mathrm{B}_{\mathrm{g}}
$$

Equation 3

Where, $G_{f}$ is the free gas volume (volume fraction), $\rho$ is the shale density $\left(\mathrm{kg} / \mathrm{m}^{3}\right), \emptyset$ is the total porosity, $S_{\mathrm{w}}$ is water saturation (volume fraction), $\mathrm{B}_{\mathrm{g}}$ is the formation volume factor (unitless), estimated using:

$$
\mathrm{B}_{\mathrm{g}}=\frac{V p t}{V s}=Z \cdot \frac{P_{s}}{T s} \cdot \frac{T}{P}
$$

Equation 4

\footnotetext{
${ }^{1}$ Gas saturation is equal to (1-Sw), if it is assumed that the entire fluid component in the pore space is either water or gas.
} 
Where, $V_{p t}$ is gas volume $\left(\mathrm{m}^{3}\right)$ under conditions of pressure $(P)$ and temperature $(T), V_{s}$ is gas volume at standard conditions $\left(\mathrm{m}^{3}\right), \mathrm{P}_{\mathrm{s}}$ is standard pressure $(101.3 \mathrm{kPa}), \mathrm{T}_{\mathrm{s}}$ is standard temperature $(298.15 \mathrm{~K}), \mathrm{T}$ is reservoir temperature (Kelvin), $\mathrm{P}$ is reservoir pressure $(\mathrm{kPa})$ and $\mathrm{Z}$ is the gas deviation factor or the gas compression factor (unitless).

ii) Adsorbed gas content

Carbon dioxide preferentially adsorbs to organic matter over methane (Chareonsuppanimit et al., 2012). In this regard, if carbon dioxide exists as a reservoir fluid, it is likely to be in an adsorbed state, rather than freely occupying interstitial pores. In this study, carbon dioxide is accounted for by analysing the frequency distribution of observed carbon dioxide readings from gas desorption, and applying appropriate correction ratios to represent the possible range of carbon dioxide concentrations. The adsorbed gas content can be estimated usingequation10(Hartman et al., 2008; Zhang et al., 2012):

$G_{\mathrm{a}}=\frac{V_{l \cdot} \cdot p}{P+P_{l}}$

Equation 5

Where, $G_{a}$ is the adsorbed gas storage capacity ( $\mathrm{m}^{3} /$ tonne), $V_{1}$ is the Langmuir volume $\left(\mathrm{m}^{3} /\right.$ tonne), $\mathrm{P}$ is the reservoir pressure $(\mathrm{kPa}), \mathrm{P}_{1}$ is the Langmuir pressure $(\mathrm{kPa})$.

The well log data, XRD, trixial and desorption data on Rosneath and Murteree shales have been used to estimate the adsorbed and free gas contents. Volume of shale is estimated by using the gamma ray logs. TOC and the porosity are also estimated using the wireline $\log$ analysis (gamma ray, caliper, resisitivity, density and sonic), laboratory data and developed relationships based on crossplots. 


\subsection{Results}

This study analysed the data obtained from Cooper Basin's Encounter-1 and Holdfast-1 wells in the Nappamerri trough, consisting of Roseneath and Murteree shale formations. Figure 6 illustrates the comparison of the Roseneath and Murteree shales with the average properties of US shales plays.

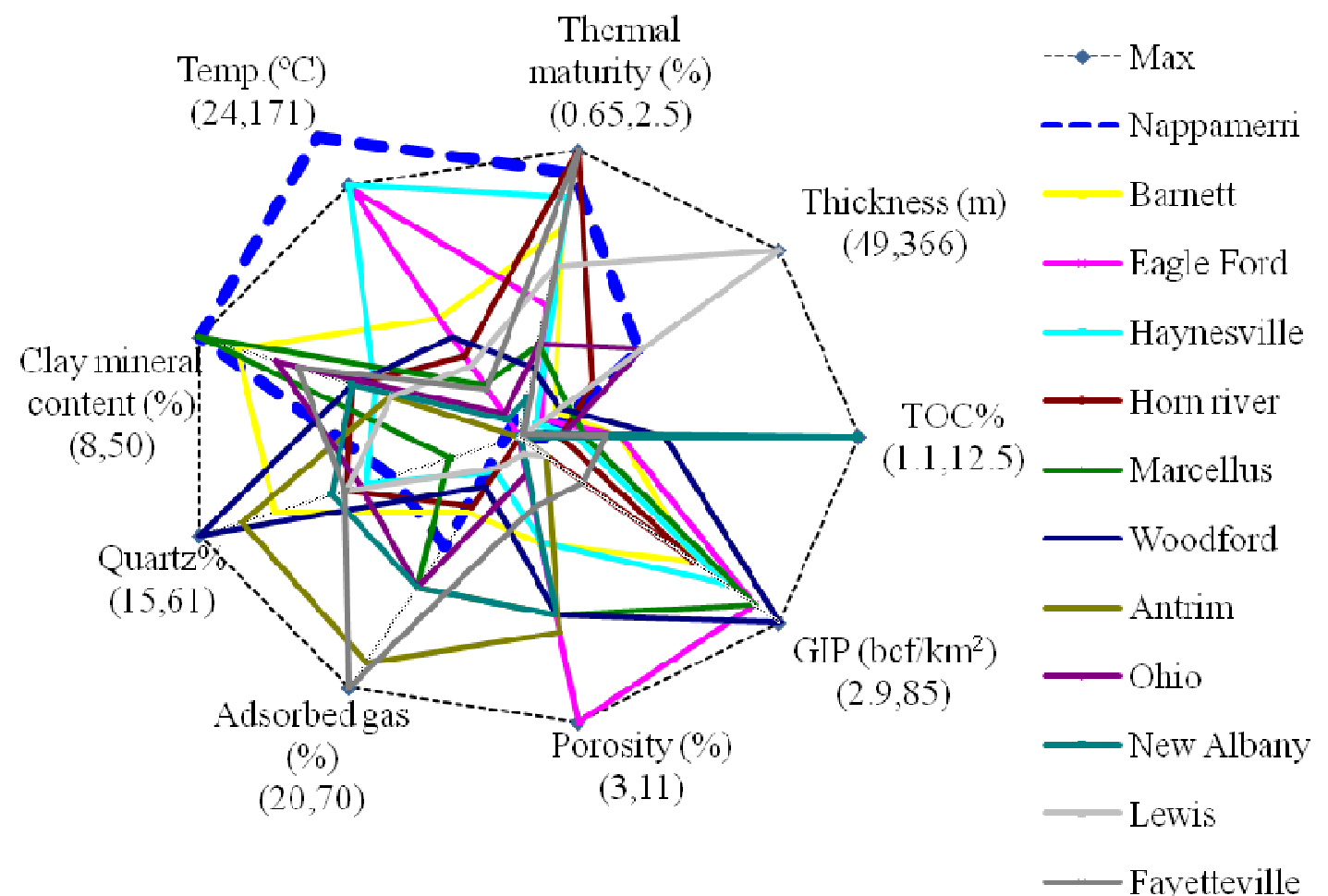

Figure 6. Comparison of in situ shale properties of Nappamerri trough with the US shales based on previous studies (Agarawal et al., 2012; Cardott, 2006; Curtis, 2002; Hexion, 2009; Kulkarni, 2011; Mckeon, 2011; Patterson, 2012; Rajtar, 2010; Schulz and Horsfield, 2010; USDOE, 2009)(limits refer to maximum average parametric values of US shale plays).

As can be seen in Figure 6, there is a large variance in the in situ properties. Geological characteristics of the Cooper basin compare well with the US shale plays, particularly in 
terms of the thickness, thermal maturity and adsorbed gas content. However, in terms of the clay mineral content and the temperature, it does not compare well with the US shale plays and values for TOC, porosity and gas-in-place are the lower end of the range. Temperature will be particularly challenging, as the fluids and equipment used for hydraulic fracturing need to be compatible with in situ temperatures and pressures. Furthermore, clay mineral content and gas-in-place will affect the commercial viability of the play, although the Roseneath and Murteree shales mostly consist of Muscovite clays, which are non-reactive to water (Table 1) (Shih and Shen, 2009). Quartz contents are considerably higher with more than $30 \%$ and there is a considerable amount of Siderite also contributing to increase the brittleness of the formations. Most importantly, kaolinite clay content is considerably lower leading to decrease the impact of swelling due to water.

Table 1: XRD results from Encounter-1 and Holdfast-1 wells

\begin{tabular}{|c|c|c|c|c|c|c|c|c|c|c|}
\hline Well & Formation & $\begin{array}{l}\text { Corr. } \\
\text { Depth } \\
\text { (m) }\end{array}$ & $\begin{array}{c}\text { Quart } \\
\text { z } \\
(\%)\end{array}$ & $\begin{array}{c}\text { Kaolinite } \\
(\%)\end{array}$ & $\begin{array}{l}\text { Siderite } \\
\mathrm{Mg}(\%)\end{array}$ & $\begin{array}{c}\text { Siderite } \\
(\%)\end{array}$ & $\begin{array}{c}\text { Rutile } \\
(\%)\end{array}$ & $\begin{array}{c}\text { Anatase } \\
(\%)\end{array}$ & $\begin{array}{l}\text { Muscovit } \\
\text { e } 2 \mathrm{M}(\%)\end{array}$ & $\begin{array}{l}\text { Muscovit } \\
\text { e } 1 \mathrm{M}(\%)\end{array}$ \\
\hline Encounter-1 & Roseneath & $\begin{array}{c}3266.95- \\
3293.50\end{array}$ & 30.50 & 14 & 2.25 & 6.75 & 1 & 1 & 34.5 & 10.75 \\
\hline Encounter-1 & Murteree & $\begin{array}{c}3493.55- \\
3536.94\end{array}$ & 31.50 & 10.5 & 7.12 & 10 & 0.94 & 0.81 & 31.38 & 8.63 \\
\hline Holdfast-1 & Roseneath & $\begin{array}{c}3118.20- \\
3162.30\end{array}$ & 35.10 & 9.60 & 1.30 & 2.90 & 1 & 1.70 & 34.80 & 13.50 \\
\hline Holdfast-1 & Murteree & $\begin{array}{r}3351.50- \\
3429.60\end{array}$ & 34.46 & 8.54 & 3.15 & 7.62 & 1 & 1.54 & 38.08 & 4.46 \\
\hline
\end{tabular}




\subsection{Adsorbed gas content}

In comparison, the Langmuir pressures of the Roseneath and Murteree Shales are similar to some of the marine shales in the US, but the Langmuir volume is notably smaller than all other shales listed in Table 2. Therefore, at a given pressure, the adsorbed gas content is considerably lower compared to US shale plays.

Table 2: Langmuir Parameters of the Roseneath and Murteree Shales, commercially producing shales in the USA (Yu and Sepehrnoori, 2013).

\begin{tabular}{|l|c|c|c|}
\hline Shale Play & $\begin{array}{c}\text { Langmuir Volume } \\
\left(\mathrm{m}^{3} / \text { tonne }\right)\end{array}$ & $\begin{array}{c}\text { Langmuir Pressure } \\
(\mathrm{kPa})\end{array}$ & $\begin{array}{c}\text { Adsorbed gas content( } \\
\text { At 55MPa })\end{array}$ \\
\hline Barnett & 2.72 & 4482 & 5.52 \\
\hline Marcellus & 5.66 & 3447 & 4.17 \\
\hline Eagle Ford & 4.95 & 10342 & 1.43 \\
\hline Haynesville & 1.70 & 10342 & 2.80 \\
\hline New Albany & 2.94 & 15515 & 1.29 \\
\hline Roseneath & 1.65 & 10173 & 1.32 \\
\hline Murteree & 1.56 & & \\
\hline
\end{tabular}

\subsection{Free gas content}

Neither formation pressure testing nor drill stem testing was performed for Encounter-1 and Holdfast-1 wells (Beach Energy, 2011a, b). Therefore, there are no measured values of reservoir pressures. Instead, the reservoir pressure is estimated by using the regional pressure 
gradients for the Cooper Basin (i.e. $9.72 \mathrm{kPa} / \mathrm{m}$ from the surface elevation to the top of the Toolachee Formation, and $16.28 \mathrm{kPa} / \mathrm{m}$ from the top of the Toolachee Formation to top of the Patchawarra Formation)(Trembath, 2013b). The estimated average free gas volumes ranged between $0.37-3.40 \mathrm{~m}^{3} /$ tonne for both formations.

\subsection{Cross plots}

Crossplots can be used to estimate the characteristics of different lithologies to establish pertinent cut offs for core-log correlations. These cut-offs can be applied to methods such as the Passey method to constrain the results. In addition, crossplots are important in identifying reservoir heterogeneity and in matching diagenetic processes, pore types and mineralogy (Passey et al., 1990). In this study, crossplots are used to compare the Cooper Basin shales with the US shales.

\subsubsection{TOC and uranium content}

For marine shales, the crossplot of TOC and uranium content is a positive relationship, as illustrated in Figure 7 (Fertl and Chilingar, 1988). Therefore, use of gamma ray wireline logs to estimate the TOC content could be feasible as the uranium content is reflective of the TOC content of the reservoir(Lüning et al., 2004). The Murteree and Roseneath shales show a weak negative relationship between uranium content and TOC, as illustrated in Figure 8. Therefore, the use of wireline log analysis to estimate the TOC will not be suitable for these shales and alternative methodologies, such as rock-eval pyrolysis, or must be conducted using core data. In this study, TOC is determined by rock-eval pyrolysis. Furthermore, the use of $\operatorname{logs}$ to estimate TOC content with the Parsey methodology is not feasible due to the maturity of the shales, over-pressure, presence of siderite and inadequacy of non-source rock for calibration (Trembath, 2013a). 


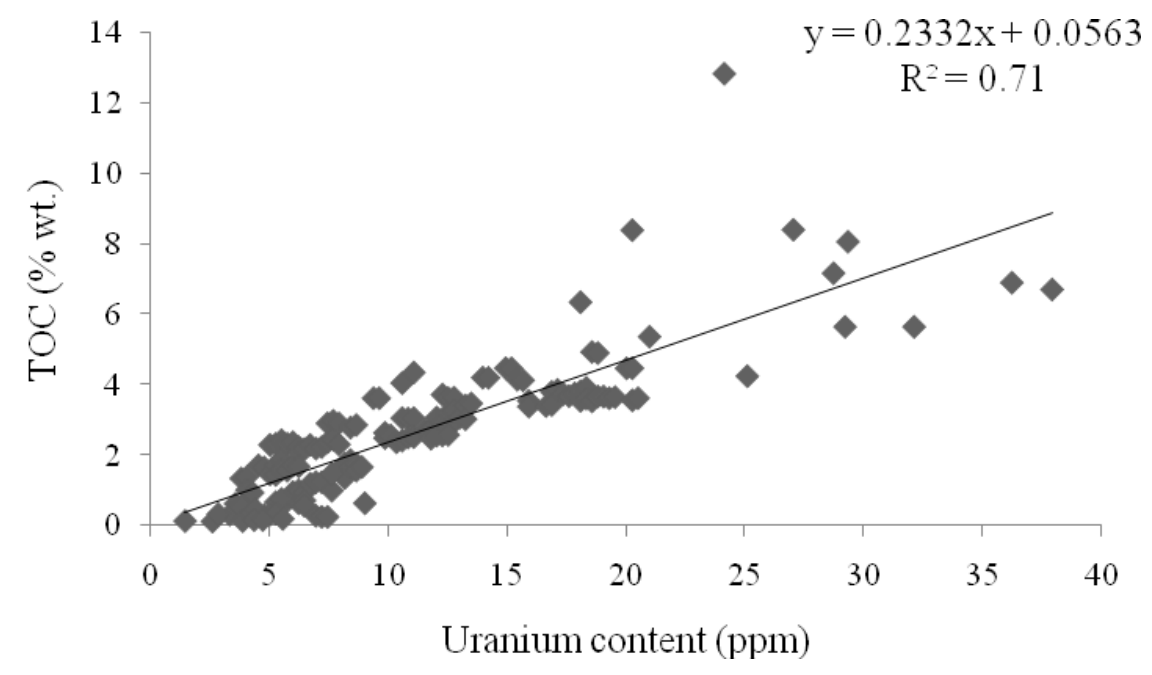

7 (a) Change of TOC with uranium content for Devonian Black shales in West Virginia,

Kentucky (Fertl and Chilingar, 1988)

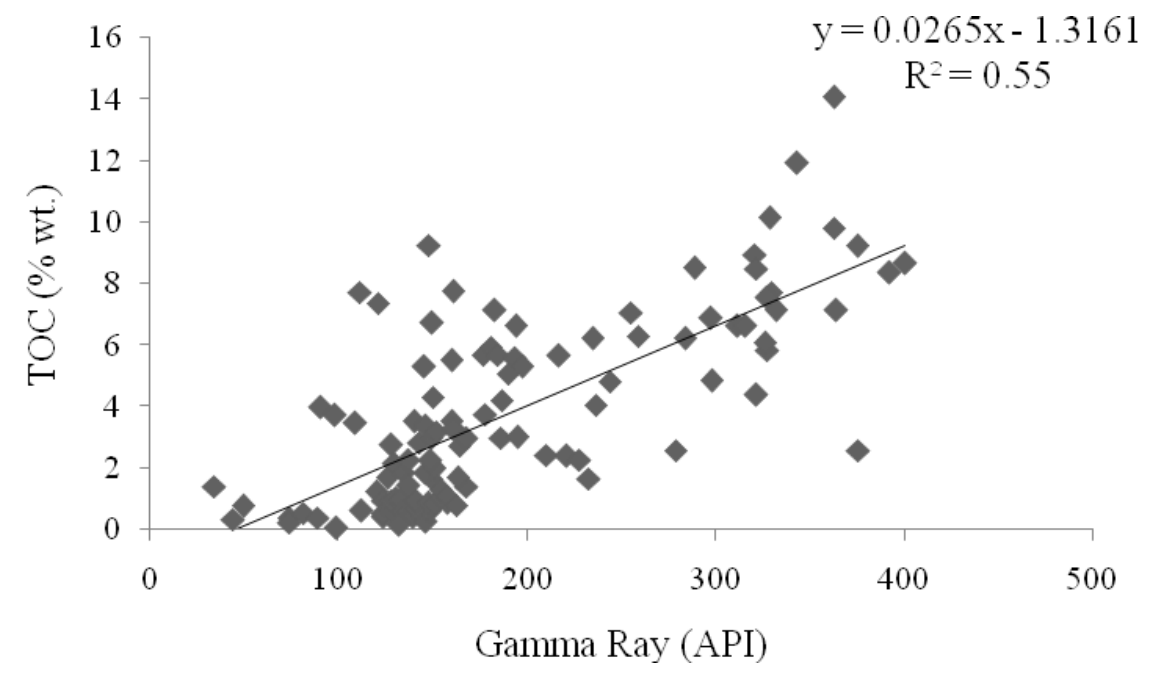

7 (b) TOC content vs Gamma ray for New Albany shale (Cluff and Miller, 2010)

Figure 7. Change of TOC content with uranium content and gamma ray content for US shales 


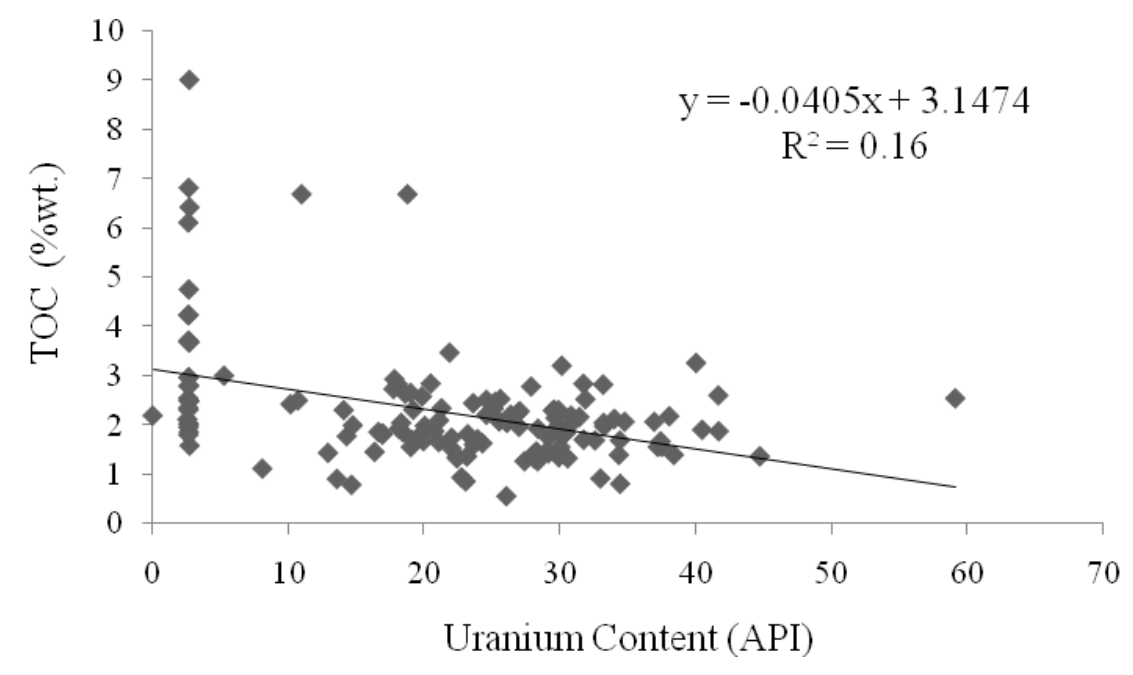

Figure 8. Change of TOC with Uranium content for Holdfast-1 and Encounter-1 wells

\subsubsection{TOC and bulk density}

Usually, TOC vs bulk density will show a negative relationship for marine shales, as illustrated by Figure 9 (Mendelson, 1985). For Holdfast-1 and Encounter-1 wells there is a weak negative relationship, as illustrated by Figure 10. However, areas with higher TOC could contain siderite, leading to increase the density, meaning that this relationship cannot be used to estimate the bulk densities at varying TOC contents for Cooper Basin shales as it is susceptible to the changes of the siderite content in the formation. 


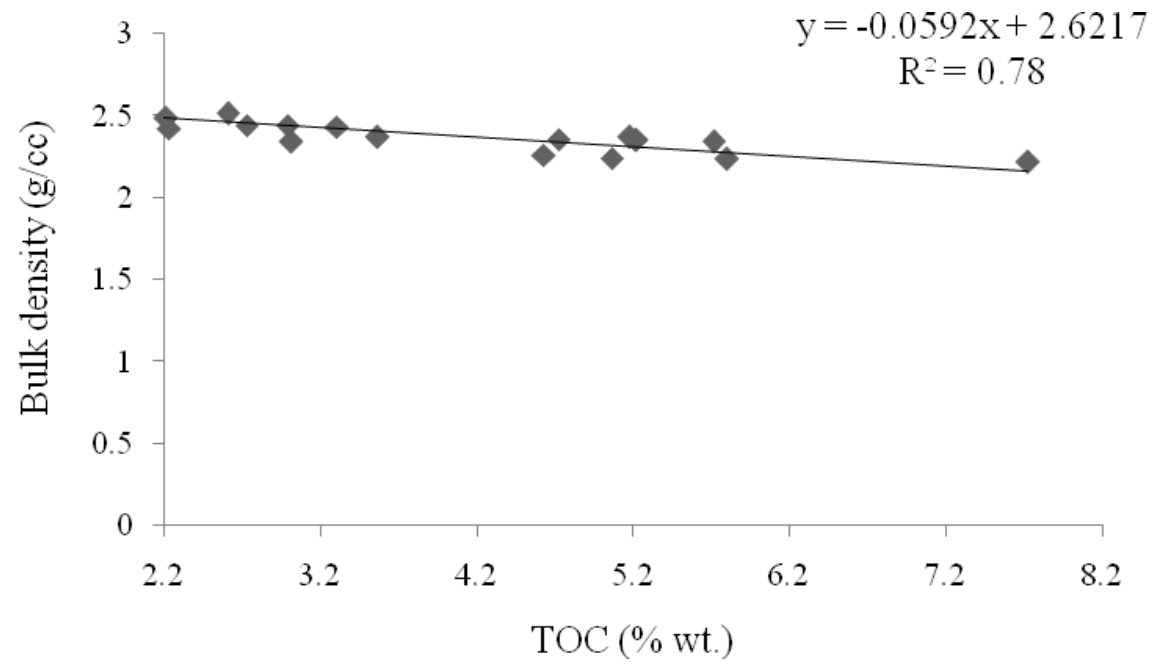

9 (a) Avalon shale (Raphael, 2012)

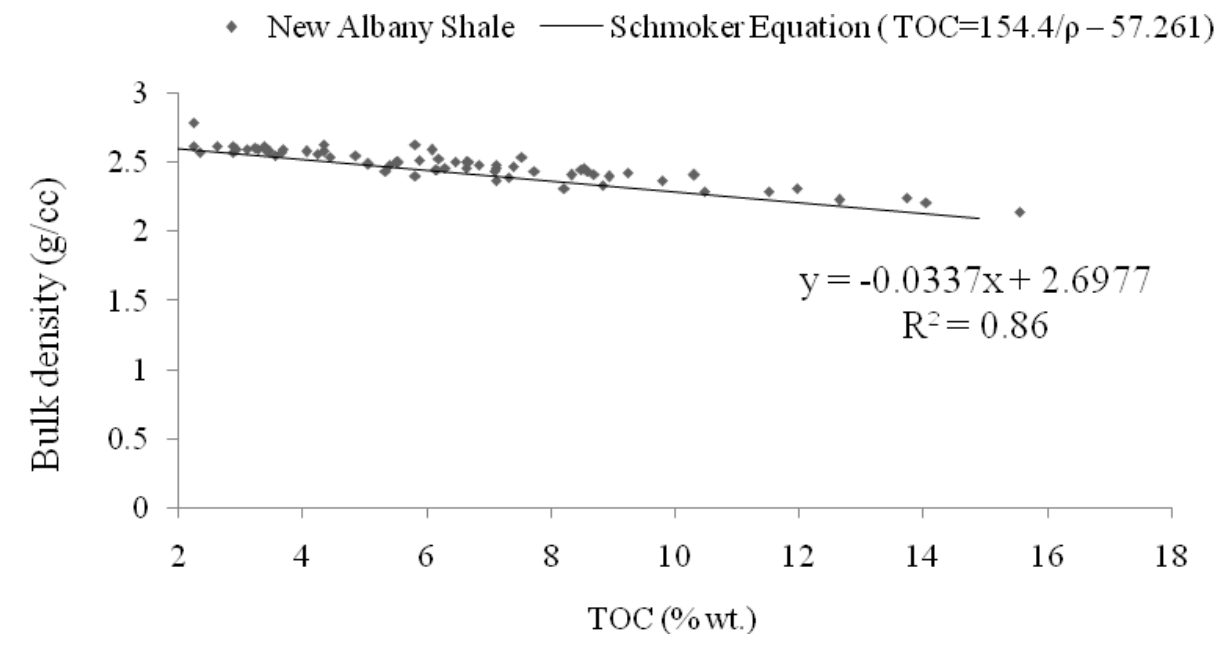

9 (b) New Albany Shale (Cluff and Miller, 2010)

Figure 9. Change of bulk density with TOC for US marine shales 


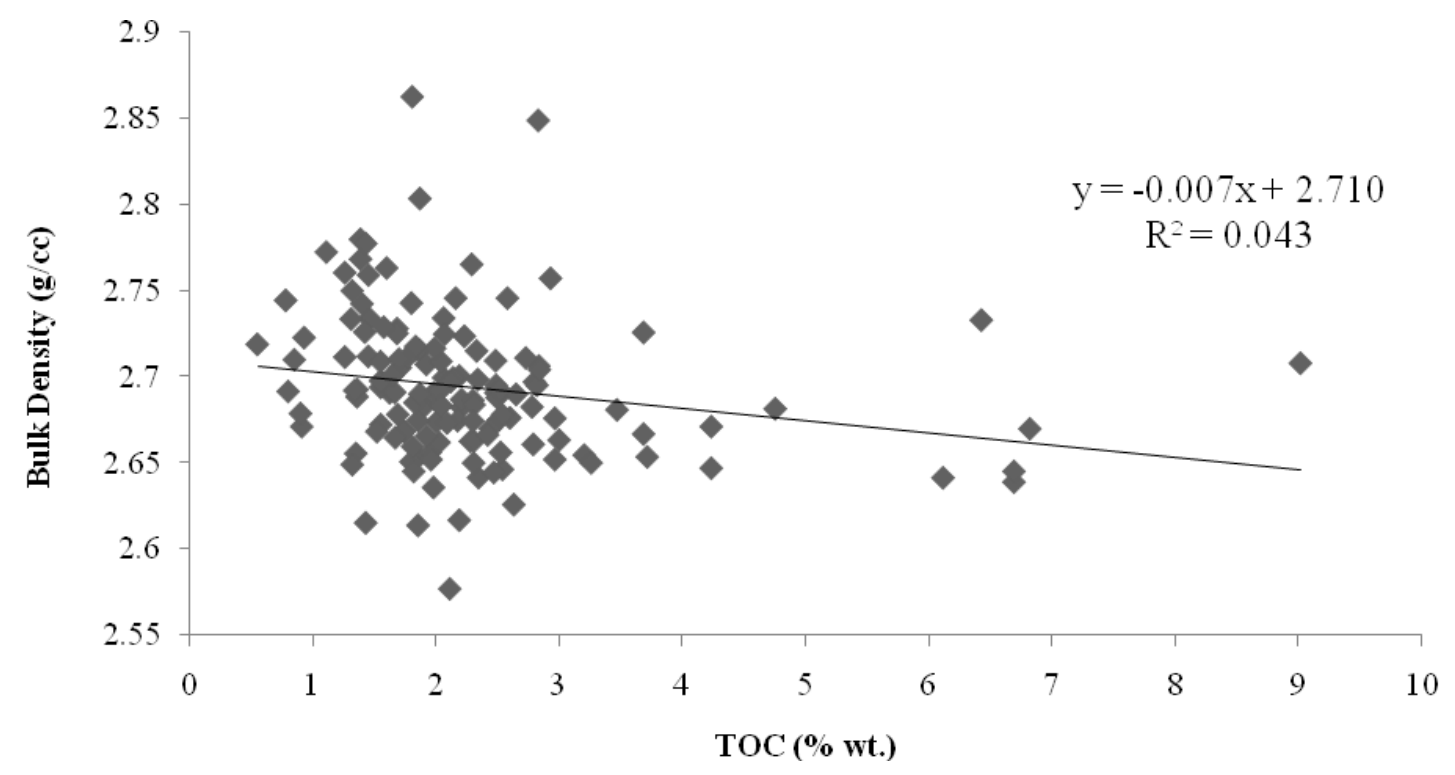

Figure 10. Change of bulk density with TOC for Roseneath and Murteree shales

\subsubsection{Bulk density and porosity}

V-shaped cross plots have been observed due to the mixing of shale and other particles at the pore scale (Figure 11). This is important for separating the porosities of different constituents. This trend has been observed for both the Roseneath and Murteree shale formations. The influence of distinctively different minerals is evidenced through this crossplot. The coal minerals may have a low density and high water content, whereas the siderite minerals could have a higher density and low water content, leading to variations of densities and porosities (Glover, 2013). 


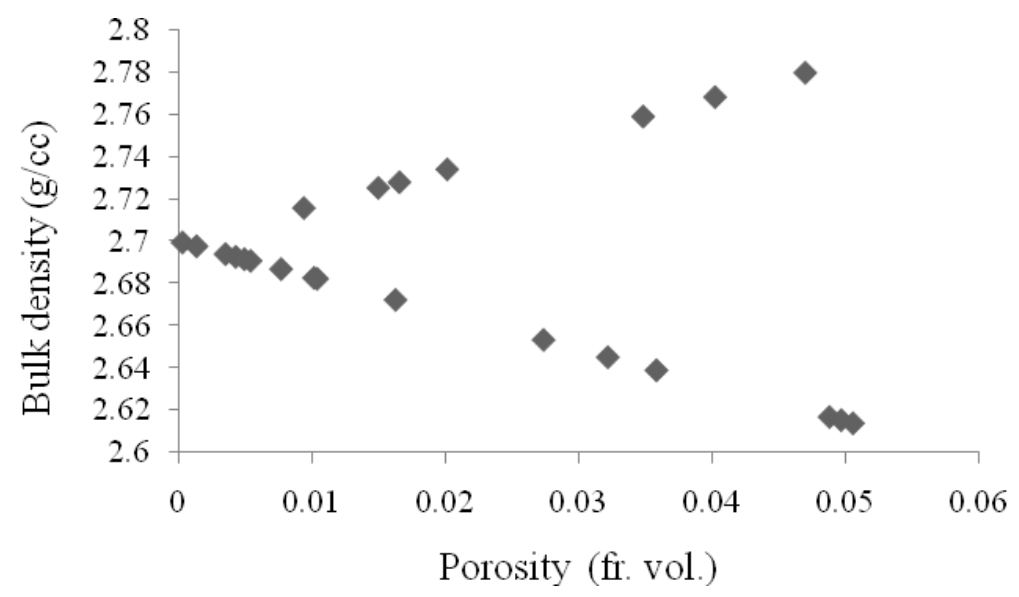

Figure 11.Crossplot of bulk density and porosity for Murteree shale

\subsubsection{Adsorbed gas content and TOC}

This relationship is important, as the adsorbed gas content can be estimated if the TOC is known for the formation. Adsorbed content is directly correlated with the organic content of the shale. The previous studies on marine shales have shown an increase of shale gas content with increasing TOC content (Table 3 and Figure 12). For Roseneath and Murteree shales, a positive relationship is also depicted between the adsorbed gas content and TOC, as illustrated in Figure 13.

Table 3: Reservoir data (EIA, 2013)

\begin{tabular}{|l|c|c|}
\hline Properties & Horn River & Rosneath and Murteree \\
\hline Thermal maturity $\left(\% \mathrm{R}_{0}\right)$ & 3.5 & 2 \\
\hline Temperature $\left({ }^{0} \mathrm{C}\right)$ & $80-160$ & $150-200$ \\
\hline Age & & Permian \\
\hline
\end{tabular}




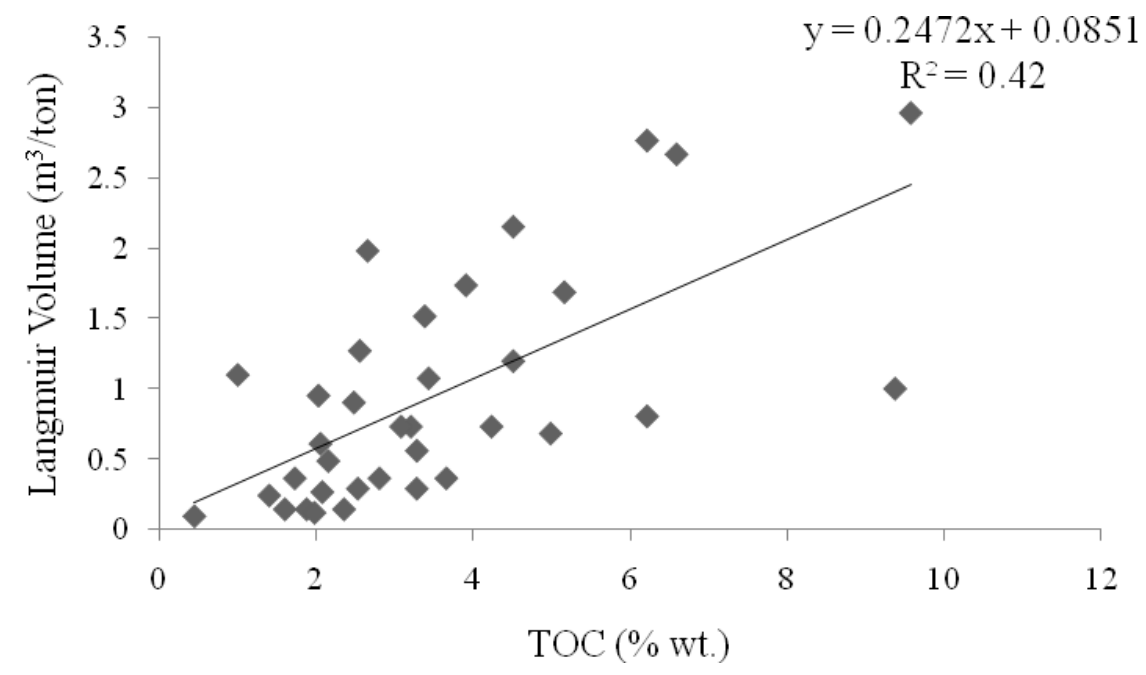

Figure 12. Change of adsorbed gas volume with TOC content for Horn River Basin (NEB, 2011)

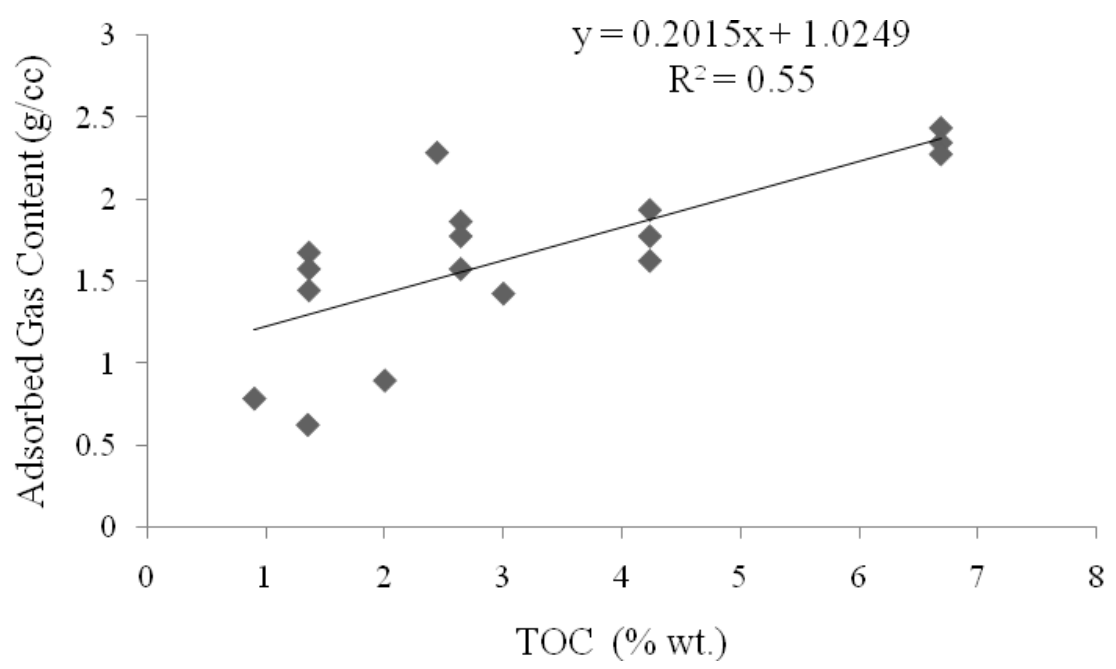

Figure 13. Change of adsorbed gas content with TOC for Holdfast-1 and Encounter-1 wells

\subsubsection{Other porosity based crossplots}

The porosity and uranium content show a weak negative relationship, as illustrated in Figure 14(a). However, the porosity has not shown a strong relationship with the TOC content 
(Figure 14 (b)). In comparison, Avalon marine shales have shown a strong linear relationship among porosity and TOC (Figure 15), enabling porosity values to be estimated at various TOC contents. Furthermore, porosity decreases with increasing carbonate content for the Avalon marine shales, as illustrated in Figure 16. Such a correlation is not observed for Murteree and Roseneath shales (Figure 17).

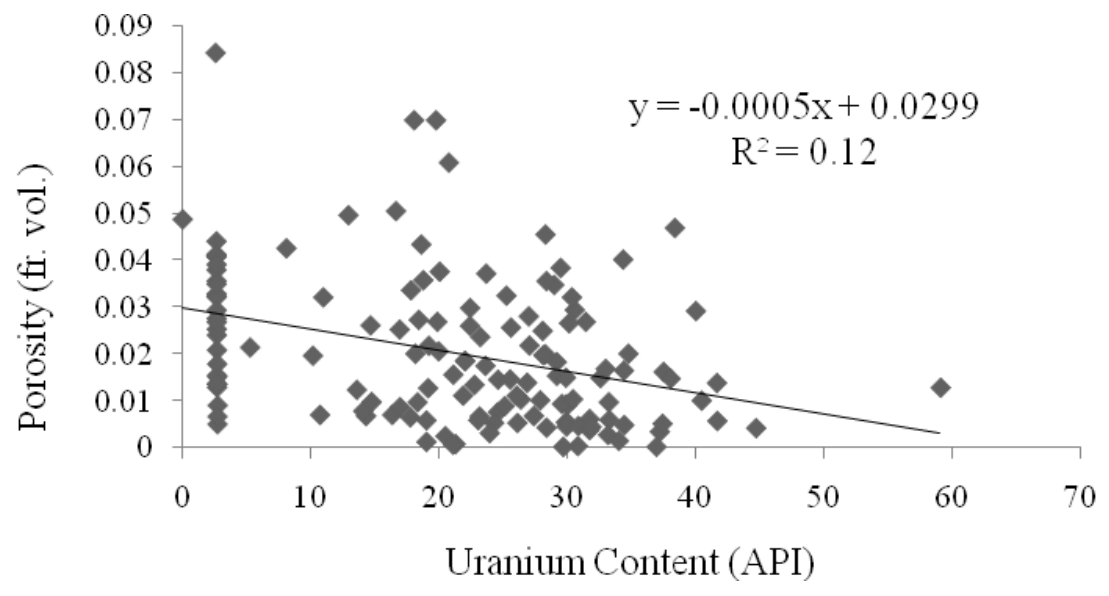

(a) Change of porosity with uranium content

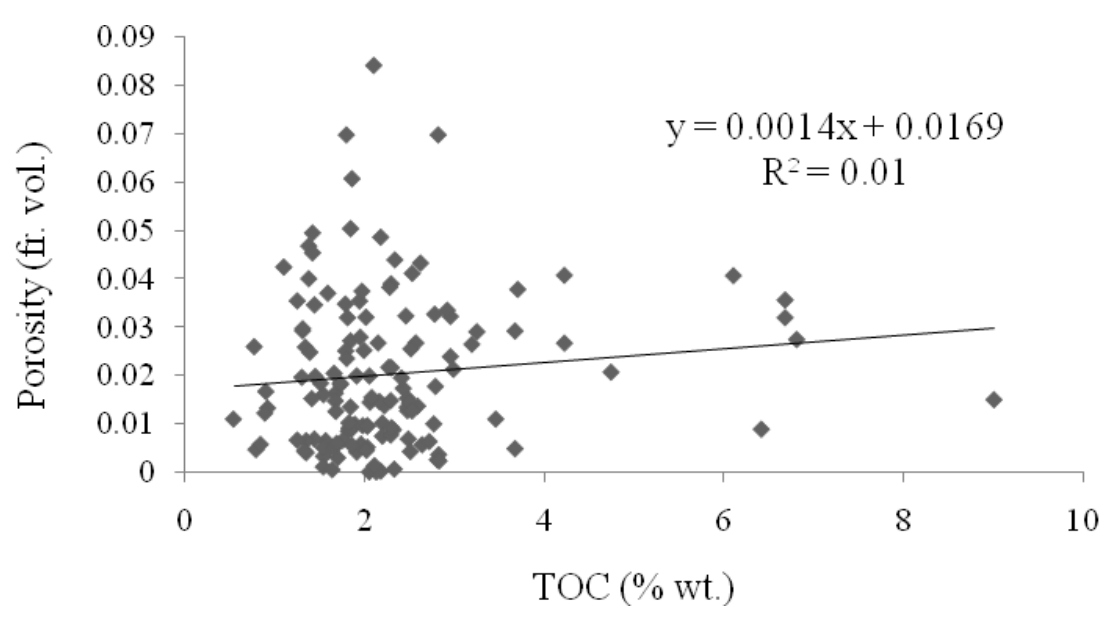

(b) Change of porosity with TOC

Figure 14.Change of porosity with TOC and uranium content for Roseneath and Murteree shales 


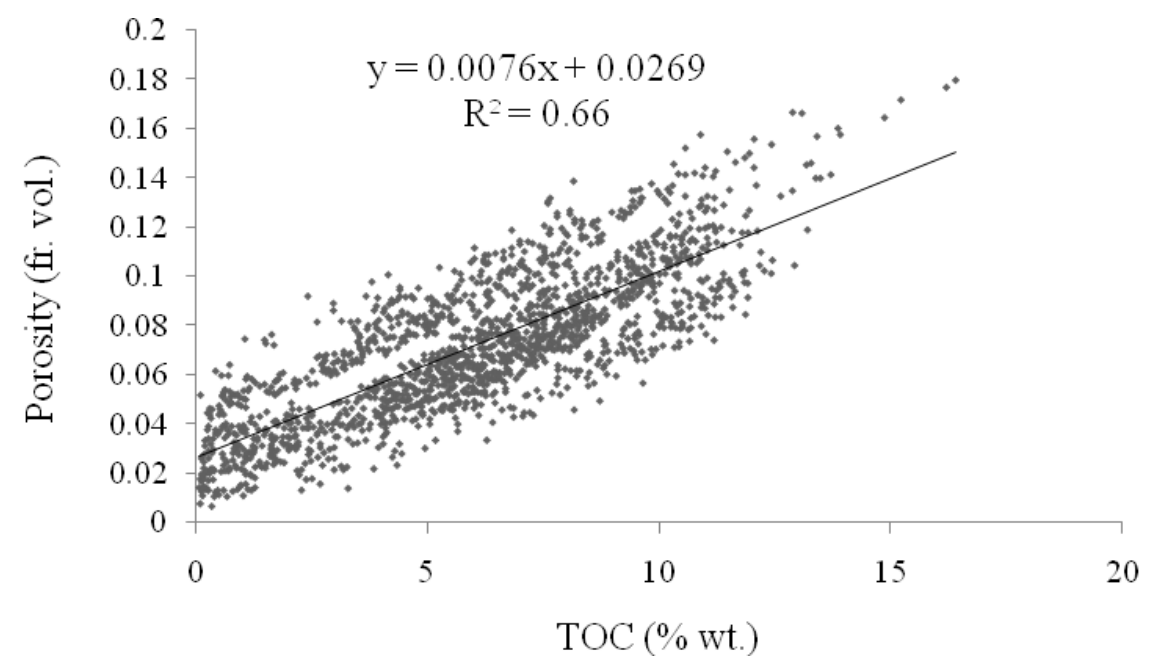

Figure 15.Porosity vs TOC for Avalon marine shale (Raphael, 2012)

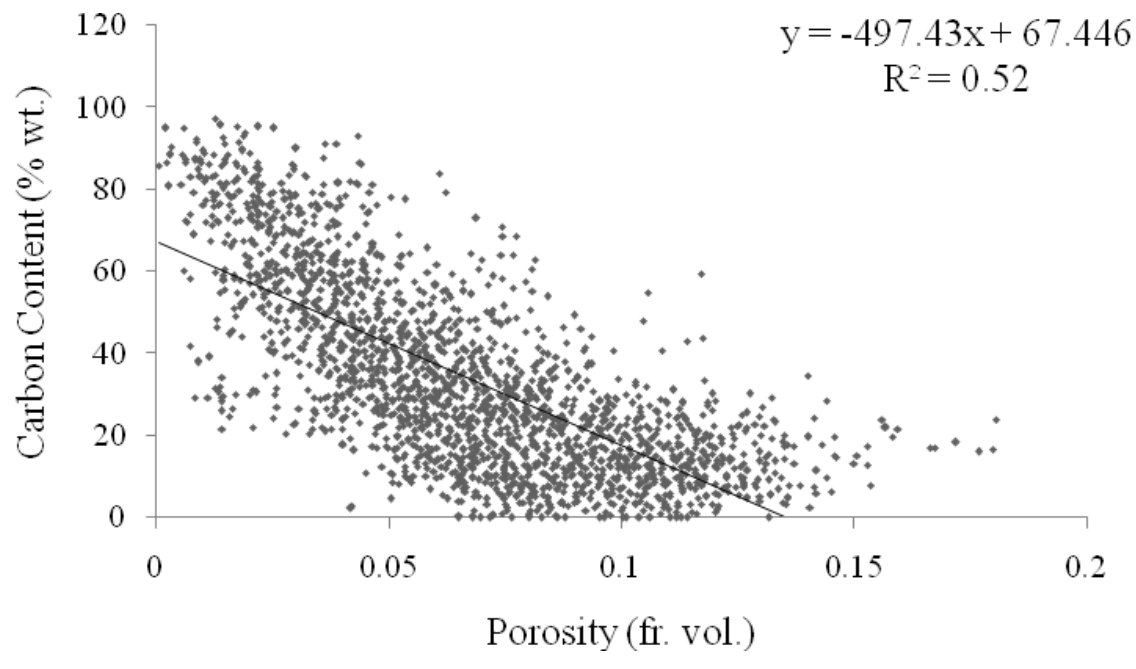

Figure 16.Change of carbonate content with porosity for the Avalon marine shales (Raphael, 2012). 


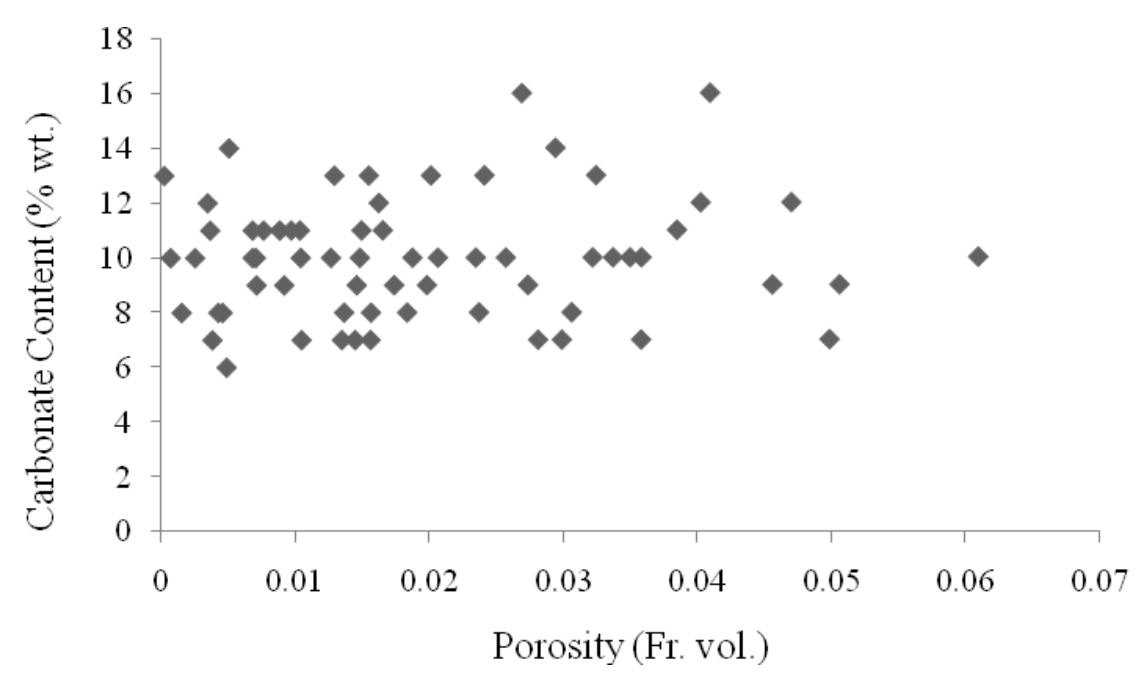

Figure 17. Change of carbonate content with porosity for Murteree and Roseneath shales

\subsubsection{Young's modulus and Poisson's ratio}

Hydraulic fracturing can stimulate the natural fractures connecting the well bore with a larger volume of rock (Gale et al., 2007). Therefore, the response to hydraulic fracturing is an important consideration in assessing the production potential. However, there are several other factors that hinder the success of the hydraulic fracturing process, such as multi-phase flow, proppant crushing, proppant diagenesis, relative permeability, capillary pressure, reservoir permeability change, operational conditions, reservoir heterogeneity and fracture fluid interaction (Osholake, 2010). Fracturing can increase the permeability by a factor of around 100- 1000 (Gaskari, 2006; Kassis, 2011).The response to hydraulic fracturing can be estimated using the Young's modulus and Poisson's ratio. Young's modulus refer to the ability to retain a fracture and the Poisson's ratio refers to the potential for fracturing (Rickman, 2008). This is more associated with the quartz content of the shale formation. In general, the larger the Young's modulus, the more brittle the rock; conversely, the smaller the Poisson's ratio, the more brittle the rock (Rickman, 2008). There is a large overlap of 
Poisson's ratios between 0.1 and 0.3 for common sedimentary rocks, such as shale, sandstone, siltstone, marl, limestone and dolomites (Gercek, 2007). However, increasing clay mineral content tends to increase Poisson's ratio, and Poisson's ratio is also sensitive to the orientation and distribution of clay minerals in the rock fabric (Guo et al., 2013). Kerogen also modifies the elastic properties of the rock significantly, especially with respect to anisotropic effects (Sayers, 2013). Figure 18 illustrates the clastic contents and mineral contents of Roseneath and Murteree shales. Although there is high clay content, there is also a substantial carbonate content, leading to an increase in the brittleness of these formations. The crossplot of Young's modulus and Poisson's ratio can be used to estimate the "fraccability" of the formations. The Woodford marine shale is more brittle (brittleness indicators: Young's modulus more than 5GPa and Poisson's ratio less than 0.25) in comparison to the Roseneath and Murteree shales (Figures19-20). Furthermore, for the Murteree shale, the brittleness index shows a strong correlation with the gamma ray content (Figure 21), whilst the Barnett shale shows a weak relationship (Figure 22). According to Table 4, most of the points for the former are located in the less brittle region. However, these properties can be regarded as adequate for hydraulic fracturing compared to other non-marine shales with lower carbonate content. The high siderite content could have contributed to the increase in brittleness.

Table 4: Brittleness classification table (Perez and Marfurt, 2013)

\begin{tabular}{|l|l|}
\hline Brittleness index & Classification \\
\hline $0-0.16$ & Ductile \\
\hline $0.16-0.32$ & Less ductile \\
\hline $0.32-0.48$ & Less brittle \\
\hline$>0.48$ & High brittle \\
\hline
\end{tabular}




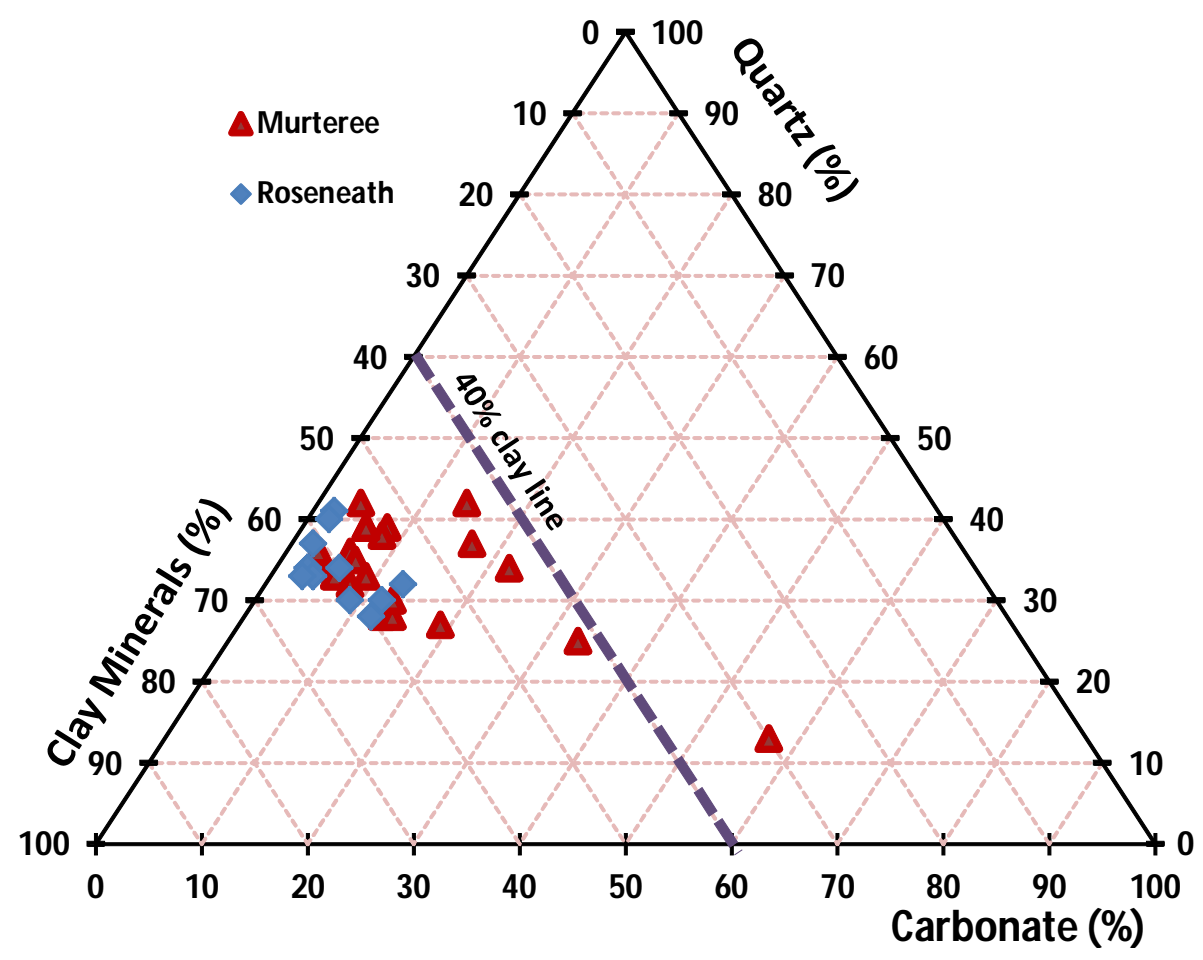

Figure 18.Ternary plot of the mineral composition of the Roseneath and Murteree shales from the XRD analysis.

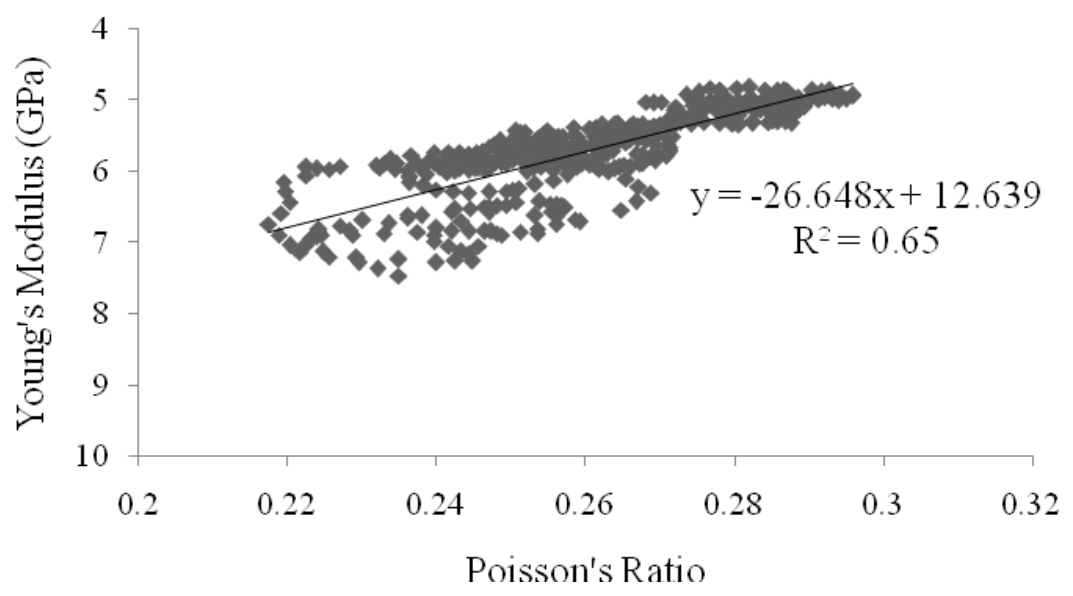

Figure 19.Young's modulus vs Poisson's ratio - Murteree shale (Trembath, 2013a) 


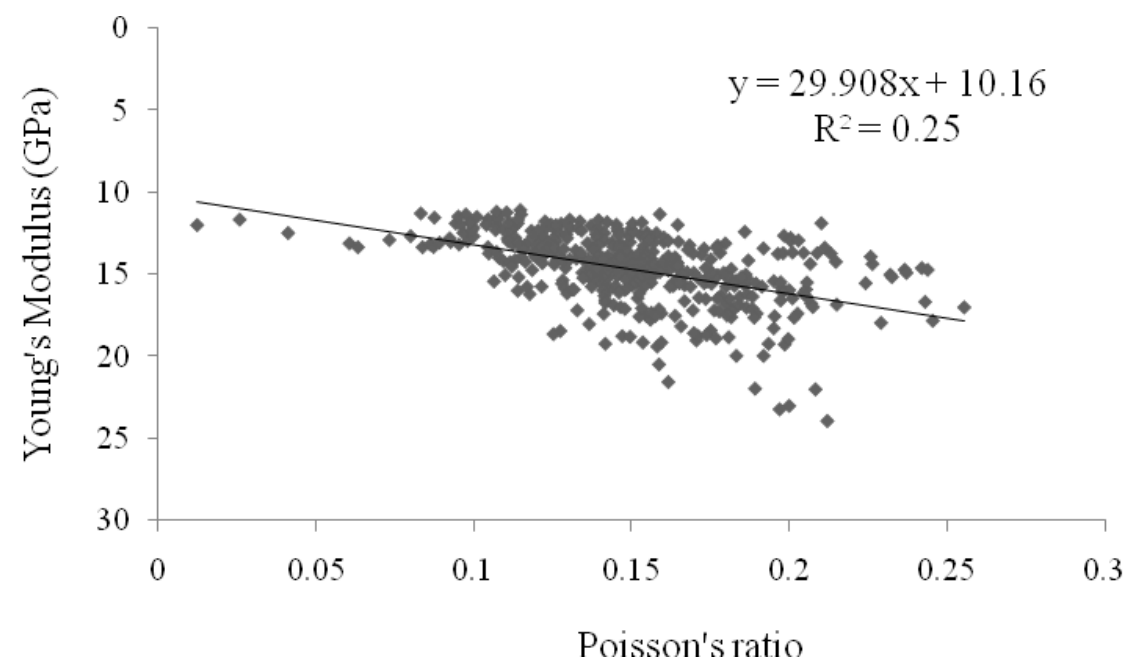

Figure 20. Young's modulus vs Poisson's ratio for Woodford shale (Harris et al., 2011)

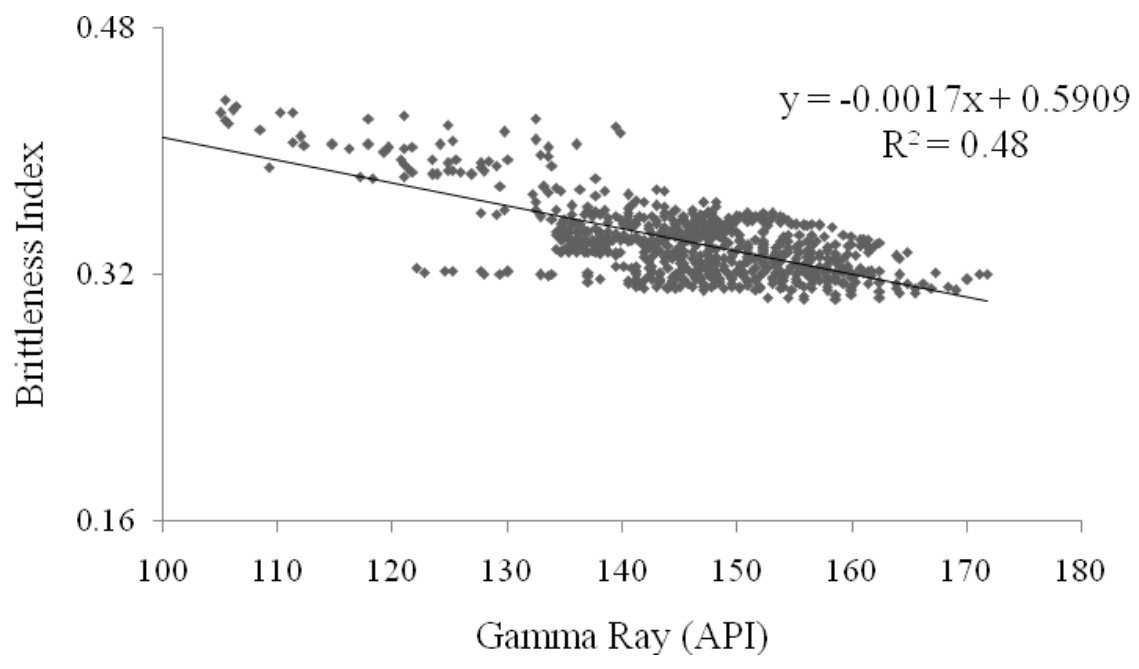

Figure 21. Change of brittleness index with gamma ray content for Murteree shale 


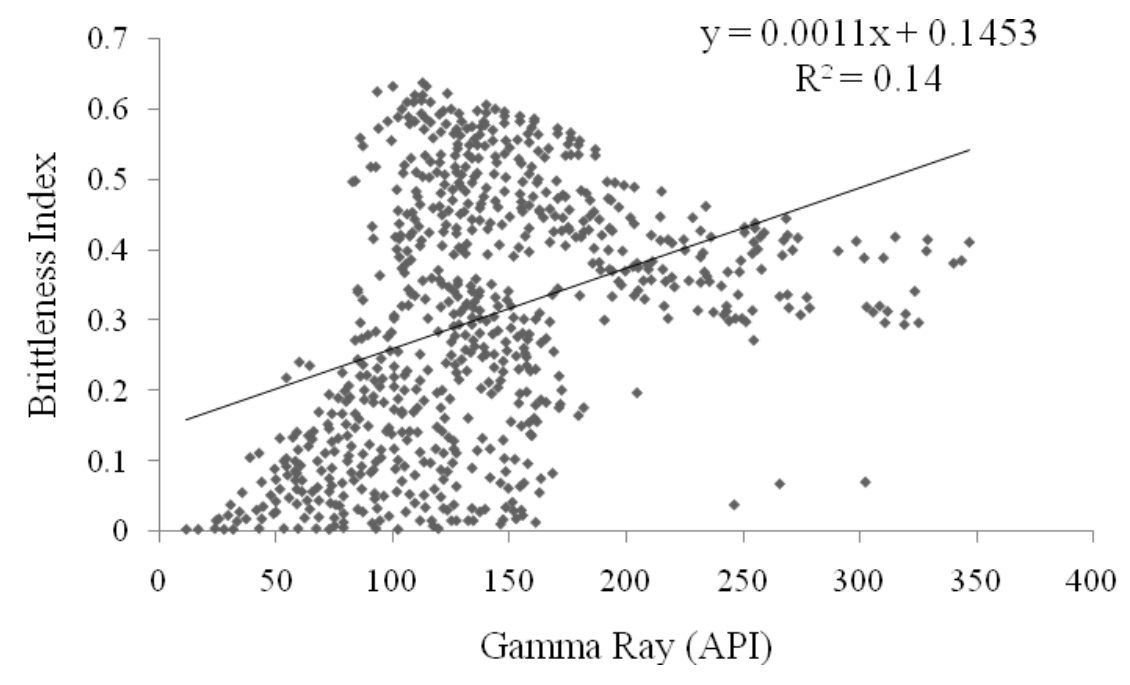

Figure 22. Change of brittleness with gamma ray for Barnett shale (Perez, 2013)

\subsection{Discussion}

Shale petrophysical analysis is critical to evaluate the shale parameters and contents. For marine shales, this is mainly related to the analysis of wireline logs and crossplots. However, for non-marine shale, this approach is not entirely applicable. In the absence of such analogues relationships, this study has developed empirical relationships for the Cooper Basin using a dataset of Roseneath and Murteree shales. However, these relationships are location specific and, thus, could only be formalized with additional research on similar shale formations. In particular, the crossplots of gamma ray and TOC, density and porosity have not shown good agreement in comparison to those for marine shales.

The potential of a shale play is mainly based on the TOC, thermal maturity and gas content. If these parameters are high enough, then it is worthwhile to continue the development of such plays. Thermal maturities of 0.6 or higher would also indicate good potential, less than this and the play would be too immature for development. Thermal maturities over $1.1 \%$ would be the most suitable for shale gas development. The Cooper Basin shales are of 
comparable thickness to US shales and thermal maturity is also over $1.1 \%$ indicating good potential for shale gas development in the Cooper Basin. However, higher thermal maturity also indicates that there is less prospect of shale oil in the basin.

The estimation of TOC based on wireline $\operatorname{logs}$ was unreliable, there being no significant relationship between the uranium and gamma ray content. Therefore, TOC values were experimentally evaluated using core samples at different depths. The free gas and adsorbed gas contents were estimated by using the wireline log analysis and isothermal experiments. The estimation of porosity was mostly appropriate via wireline logs, as it is more representative of the field scale. The adsorbed gas content was estimated using adsorption data observed in the laboratory, as the adsorbed gas content could not be estimated directly from the wireline logs. The adsorbed gas content is dependent on the Langmuir parameters and adsorbed phase densities. Therefore, it is best estimated using core samples on a triaxial apparatus at isothermal conditions. The adsorbed gas and free gas contents were found to be comparable with the US marine shale data.

Crossplots are also an effective means of shale gas resource estimation. However, most of the previous methodologies applicable to US marine shales are not applicable to the Australian Roseneath and Murteree shales. The crossplot of bulk density and TOC have shown a decreasing relationship for marine shales as well as a good agreement with the Schmoker equation, which is an empirical equation based on the US marine shale data. However, Roseneath and Murteree shales neither show a good agreement with the Schmoker equation nor a substantive relationship among bulk density and TOC. Crossplots of permeability and porosity have depicted an increasing relationship, suggesting a high influence of porosity. However, the degree of relationship is not as strong as for the sandstones with a high emphasis on porosity, which may be due to the smaller particle grain sizes. Generally, 
particles with higher grain sizes would have higher permeabilities compared to particles with smaller grain sizes. Bulk density and porosity crossplots also have shown similar characteristics as the marine shales, depicting the influence of different constituents. Therefore, these crossplots could be calibrated to evaluate the influence of different mineral types. Adsorbed gas content and free gas content ranged from $1.29-1.32 \mathrm{~m}^{3} /$ tonne and0.37$3.40 \mathrm{~m}^{3} /$ tonne, respectively. Adsorbed gas content and TOC crossplot have shown an increasing relationship depicting the influence of organic content, to increasing the adsorption potential. Similar characteristics have been shown for coals where increasing carbon content or coal rank have led to higher adsorbed gas content (Carroll and Pashin, 2003). Crossplots of adsorption-TOC and permeability-porosity have depicted high correlation levels with coefficient of determinants of 0.55 and 0.99 respectively. However, porosity has not shown a direct relationship with the TOC or carbonate content. This could mainly be due to the presence of smaller particle sizes and high in situ pressures.

Finally, Young's modulus and Poisson's ratio have been used to estimate the potential effectiveness of hydraulic fracturing. The Roseneath and Murteree shales were found to be less brittle than the US shales (brittleness index ranged between 0.32-0.48), be due to the considerably higher clay mineral content and coal interbeds, though the presence of other clastic minerals, such as siderites, will contribute to an increase in the brittleness of the formations.

\subsection{Conclusions}

Natural gas extraction from shale gas reservoirs has gathered momentum around the world, as a result of the resounding success of US shale plays. However, the variability of shale geological conditions makes replicating the US shale gas success elsewhere a major 
challenge. An evaluation of the formation characteristics may lead to a reliable methodology for the assessment of extraction potential. In this study, the geological and petrophysical characteristics of potential Australian shale plays have been compared with those of the US shale plays. The geological and petrophysical properties have been evaluated using wireline logs, crossplots and gas content estimations. The gas contents have shown to be on par with the US gas contents. However, the crossplots have not shown the familiar co-relationships of the marine shales and empirical relationships have therefore been developed for Roseneath and Murteree shales based on the well log data and experimental data. These empirical formulae will only be applicable to specific local conditions and needs further research studies to formalise as co-relationships. Cooper basin shales have shown higher brittleness than the clay content would indicate, probably due to the higher siderite content and nonreactiveness nature of the clay content itself.

Shale gas development in the Cooper basin of South Australia may only become commercially viable when international gas prices become high enough to balance out the high production costs, caused by the significant geological challenges of high pressures, temperatures and clay contents. These challenges can only be resolved by conducting adequate research on the local shale plays to enable the development of the necessary production methods. Innovative technological options, such as enhanced gas recovery using carbon dioxide (where the carbon dioxide preferentially adsorbs onto the coal network, particularly under supercritical conditions), may need to be considered. Such techniques may increase the shale development potential, although their commercial suitability still needs to be proven. 


\subsection{Acknowledgements}

The authors wish to acknowledge the support of Beach Energy, South Australia, in this study.

\subsection{References}

ACOLA, 2013. Engineering energy: Unconventional gas production : A study of shale gas in Australia. Australian Council of Learned Academies, http://www.acola.org.au/PDF/SAF06FINAL/Final\%20Report\%20Engineering\%20Energy\%2 0June\%202013.pdf (Accessed on 14/01/2015).

Agarawal, A., 2009. A technical and economic study of completion techniques in five emerging u.s. gas shale plays, Petroleum Engineering. Texas A\&M University, Austin.

Agarawal, A., Wei, Y., Holditch, S.A., 2012. A technical and economics study of completion techniques in five emergining US gas shales: A Woodford shale example, SPE Annual Technical Conference. Society of Petroleum Engineers, Florence, Italy.

Alexander, T., Baihly, J., Boyer, C., Clark, B., Jochen, V., Calvez, J.L., Lewis, R., Miller, C.K., Thaeler, J., Toelle, B.E., 2011. Shale gas revolution, Oilfield Review. Schlumberger, USA.

Alimoradi, A., Moradzadeh, A., Bakhtiari, M.R., 2011. Methods of water saturation: historical perspective. Journal of Petroleum and Gas Engineering 2, 45-53.

Arop, J.B., 2013. Geomechanical Review of Hydraulic Fracturing Technology, Department of Civil and Environmental Engineering. Massachusetts Institute of Technology, Cambridge, Massachusetts.

Asquith, G.B., Gibson, C.R., 1982. Basic well log analysis for geologists, AAPG Methods in Exploration Series no. 5, Tulsa, Oklahoma, USA, pp. 96-99. 
Australia, G., 2010. Oil and Gas Resources of Australia - 2010, http://www.ga.gov.au/datapubs/data-and-publications-search/publications/oil-gas-resources-australia/2010 (Accessed on $11 / 02 / 2015)$

Averitt, P., 1975. Coal resources of the United States. U.S. Geol. Surv. Bull. 1412.

Bai, B., Elgmati, M., Zhang, H., Wei, M., 2013. Rock characterization of Fayetteville shale gas plays. Fuel 105, 645-652.

Beach Energy, 2011a. Encounter-1 well completion report, PEL218. Beach Energy Ltd, Adelaide, South Australia.

Beach Energy, 2011b. Holdfast-1 well completion report, PEL218. Beach Energy Ltd, Adelaide, South Australia.

Beach Energy, 2015. Porosity estimation using denisty logs as neutron and sonic logs were affected by clay bound water, in: Silva, N.D. (Ed.). Private Communication.

Boyer, C., Clark, B., Jochen, V., Lewis, R., Miller, C.K., 2011. Shale gas : A global resource, Oilfield Review. Schlumberger, USA.

Burnham, A., Han, J., Clark, C.E., Wang, M., Dunn, J.B., Palou-Rivera, I., 2011. Life-Cycle Greenhouse Gas Emissions of Shale Gas, Natural Gas, Coal, and Petroleum. Environ. Sci. Technol. 46, 619-627.

Bust, V.K., Majid, A.A., Oletu, J.U., Worthington, P.F., 2013. The petrophysics of shale gas reservoirs: technical challenges and pragmatic solutions, International Petroleum Technology Conference. International Petroleum Technology Conference Bangkok, Thailand.

C2ES, 2013. Leveraging natural gas to reduce greenhouse gas emissions. Center for Climate and Energy Solutions, http://www.c2es.org/docUploads/leveraging-natural-gas-reduce-ghgemissions.pdf (Accessed on 04.02.2014).

Cardott, B.J., 2006. Data relevant to Oklahoma gas shales, SWS/EMD Shale Gas Workshop. Oaklahoma Geological Survey, Midland, TX. 
Cardott, B.J., 2012. Thermal maturity of Woodford Shale gas and oil plays, Oklahoma, USA. Int. J. Coal Geol. 103, 109-119.

Carroll, R.E., Pashin, J.C., 2003. Relationship of sorption capacity to coal quality: $\mathrm{CO}_{2}$ sequestration potential of coalbed methane reservoirs in the Black Warrior basin: Tuscaloosa, Alabama, University of Alabama College of Continuing Studies, International Coalbed Methane Symposium Proceedings. Geological survey of Alabama State Oil and Gas Board, Tuscaloosa, AL.

Chareonsuppanimit, P., Mohammad, S.A., Robinson Jr, R.L., Gasem, K.A.M., 2012. Highpressure adsorption of gases on shales: Measurements and modeling. Int. J. Coal Geol. 95, $34-46$.

Chou, E., 2013. Shale gas in China : Development and Challenges. Harvard University, http://blogs.law.harvard.edu/ellachou/files/2013/07/Shale-Gas-in-China-Draft.pdf.

Clarkson, C.R., 2013. Production data analysis of unconventional gas wells: Review of theory and best practices. Int. J. Coal Geol. 109-110, 101-146.

Clarkson, C.R., Jensen, J.L., Blasingame, T.A., 2011. Reservoir engineering for unconventional gas reservoirs: What do we hvae to consider?, SPE North American Unconventional Gas Conference Exhibition Society of Petroleum Engineers, Woodlands, Texas, USA.

Cluff, B., Miller, M., 2010. Log evaluation of gas shales a 35-year perspective.

Curtis, J.B., 2002. Fractured shale-gas systems. American Association of Petroleum Geologists 86, 1921-1938.

Curtis, M.E., Cardott, B.J., Sondergeld, C.H., Rai, C.S., 2012. Development of organic porosity in the Woodford Shale with increasing thermal maturity. Int. J. Coal Geol. 103, 2631. 
Dawson, W.C., 2000. Shale microfacies: Eagle Ford Group (Cenomanian-Turonian) NorthCentral Texas outcrops and subsurface equivalents. Gulf Coast Association of Geological Societies Transactions 50 .

Day-Stirrat, R.J., Loucks, R.G., Milliken, K.L., Hillier, S., van der Pluijm, B.A., 2008. Phyllosilicate orientation demonstrates early timing of compactional stabilization in calcitecemented concretions in the Barnett Shale (Late Mississippian), Fort Worth Basin, Texas (U.S.A). SedG 208, 27-35.

Decker, A.D., Hill, D.G., Wicks, D.E., 1993. Log-based gas content and resource estimates for the Antrim shale, Michigan basin, SPE Rocky Mountain Regional/Low Permeability Reservoirs Symposium. Society of Petroleum Engineers, Denver, CO.

Dello, L., 2014. Unlocking the Cooper Basin's resource potential, http://www.atse.org.au/Documents/Events/SA\%20Manufacturing/lou-dello-unlockingcooper-basin.pdf ( Accessed on 03.03.2014).

Deshpande, V.P., 2008. General screening criteria for shale gas reservoirs and production data analysis of Barnett shale. Texas A \& M university, Texas.

DMITRE, 2012a. Roadmap for unconventional gas projects in south australia. Department for Manufacturing,Innovation, Trade,Resources and Energy, http://www.petroleum.dmitre.sa.gov.au/_data/assets/pdf_file/0008/179621/Roadmap_Uncon ventional_Gas_Projects_SA_12-12-12_web.pdf (Accessed on 5/08/2014).

DMITRE, 2012b. Shale gas Primary Industries and Resources SA, Aus.

DMITRE, 2013. Cooper Basin, http://www.pir.sa.gov.au/petroleum/prospectivity/basin_and_province_information/prospecti vity_cooper (Accessed on 16.04.2014).

Dong, Z., Holditch, S.A., McVay, D.A., 2013. Resource evaluation for shale gas reservoirs. SPE Economics and Management, 5-16. 
EIA, 2011. Review of emerging resources: U.S. shale gas and oil shale plays. U.S. Department of Energy, Washington, DC 20585.

EIA, 2013. Technically Recoverable Shale Oil and Shale Gas Resources: An Assessment of 137 Shale Formations in 41 Countries Outside the United State. ARI, http://www.advres.com/pdf/A EIA ARI 2013\%20World\%20Shale\%20Gas\%20and\%20Shale\%200il\%20R esource\%20Assessment.pdf (Accessed on 29/01/2015).

EIA, 2014. Annual Energy Outlook, http://www.eia.gov/forecasts/aeo/data.cfm.

EIA, 2015. Spot prices for crude oil and petroleum products. Energy Information Administration, http://tonto.eia.gov/dnav/pet/hist/LeafHandler.ashx?n=PET\&s=RWTC\&f=A. EY, 2013. Shale gas in Europe: revolution or evolution? Ernst \& Young, http://www.ey.com/Publication/vwLUAssets/Shale_gas_in_Europe_revolution_or_evolution/ \$File/EY-Shale_gas_in_Europe-revolution_or_evolution.pdf (Accessed on 22/01/2015).

Fertl, W.H., Chilingar, G.V., 1988. Total organic carbon content determined from well logs. SPE Economics and Management.

Gale, J.F.W., Reed, R.M., Holder, J., 2007. Natural fractures in the Barnett Shale and their importance for hydraulic fracture treatments. AAPG Bull. 91, 603-622.

Gaskari, R., 2006. Estimating major and minor natural fracture pattern in gas shales using production data, 2006 SPE Eastern Regional Meeting, Canton, OH, USA.

Gercek, H., 2007. Poisson's ratio values for rocks. Int. J. Rock Mech. Min. Sci. 44, 1-13.

Glorioso, J.C., Rattia, A., 2012. Unconventional reservoirs: basic petrophysical concepts for shale gas, SPE/EAGE Unconventional Resources Conference and Exhibition. Society of Petroleum Engineers, Vienna, Austria.

Glover, P., 2013. Petrophysics MSc course notes. Laval University, http://www2.ggl.ulaval.ca/personnel/paglover/CD\%20Contents/GGL66565\%20Petrophysics\%20English/Contents.PDF (Accessed on 24.02.2014). 
Govt, S., 2012. Roadmap for unconventional gas projects in South Australia

Guo, Z., Li, , Liu, X.X., Feng, C.X., Shen, Y., 2013. A shale rock physics model for analysis of brittleness index, mineralogy and porosity in the Barnett Shale. JGE 10.

Haluszczak, L.O., Rose, A.W., Kump, L.R., 2013. Geochemical evaluation of flowback brine from Marcellus gas wells in Pennsylvania, USA. Appl. Geochem. 28, 55-61.

Handwerger, D.A., Willberg, D., Pagels, M., Rowland, B., Keller, J.F., 2012. Reconciling retort versus Dean Stark measurements on tight shales, SPE Annual Technical Conference and Exhibiton. Society of Petroleum Engineers, San Antonio, Texas, USA

Harris, N.B., Miskimins, J.L., Mnich, C.A., 2011. Mechanical anisotropy in the Woodford Shale, Permian Basin: Origin, magnitude, and scale. The Leading Edge 30, 284-291.

Hartman, R.C., 2008. Shale gas core analyses required for gas reserve estimates.

Hartman, R.C., Ambrose, R.J., Akkutlu, Y., Clarkson, C.R., 2011. Shale gas-in-place calculations part II - multi-component gas adsorption effects, SPE Unconventional Gas Conference. Society of Petroleum Engineers, Woodlands, Texas, USA.

Hartman, R.C., Lasswell, P., Bhatta, N., 2008. Recent advances in the analytical methods used for shale gas reservoir gas-in-place assessment, AAPG Annual Convention, San Antonio, Texas.

Hexion, 2009. What's working in the Fayetteville and Barnett Plays?, fracline. Hexion. Hill , T., 2010. Unconventional oil and gas opportunities in south Australia. DMITRE, Enery Resources Division.

Howarth, R.W., Ingraffea, A., Engelder, T., 2011. Natural gas: Should fracking stop? Nature $477,271-275$.

Huang, J., Zou, C., Li, J., Dong, D., Wang, S., Wang, S., Cheng, K., 2012. Shale gas generation and potential of the Lower Cambrian Qiongzhusi Formation in the Southern Sichuan Basin, China. Pet. Explor. Dev. 39, 75-81. 
Jaramillo, P., Michael Griffi, W., Matthews, H.C., 2007. Comparative Life-Cycle Air Emissions of Coal, Domestic Natural Gas, LNG, and SNG for Electricity Generation. Environ. Sci. Technol. 41, 6290-6296.

Jarvie, D.M., 2012. Components and processes affecting producibility and commerciality of shale resource systems, International Symposium on Shale Oil Technologies. Worlwide Geochemistry, LLC, Wuxi, China.

Jenner, S., Lamadrid, A.J., 2013. Shale gas vs. coal: Policy implications from environmental impact comparisons of shale gas, conventional gas, and coal on air, water, and land in the United States.

Johnson, C., Boersma, T., 2013. Energy (in)security in Poland the case of shale gas. Energy Policy 53, 389-399.

Kassis, S.M., 2011. Fracture permeability in the Barnett shale: Effects of roughness, fracture offset, proppant, and effective stress, AAPG Annual Convention and Exhibition, Houston, Texas.

Ker, P., 2013. US shale gas may become export rival to Australia.

KPMG, 2011. Shale gas - A global perspective.

Kuila, U., Prasad, M., 2013. Specific surface area and pore-size distribution in clays and shales. GeopP 61, 341-362.

Kulkarni, P., 2011. An unconventional play with conventional E \& P constraints, Shale Energy - Developing the Woodford. Schlumberger, https://slb.com/ /media/Files/industry_challenges/unconventional_gas/industry_articles/2011 08_wo_woodford_shale_complexities.pdf (Accessed on 29/01/2015).

Leather, D.T.B., Bahadori, A., Nwaoha, C., Wood, D.A., 2013. A review of Australia's natural gas resources and their exploitation. J. Nat. Gas Sci. Eng. 10, 68-88. 
Lee, D.S., Herman, J.D., Elsworth, D., Kim, H.T., Lee, H.S., 2011. A critical evaluation of unconventional gas recovery from the Marcellus shale, northeastern United States. KSCE J. Civ. Eng. 15, 679-687.

Lewis, R., Ingraham, D., Pearcy, M., Williamson, J., Sawyer, W., Frantz, J., 2004. New evaluation techniques for gas shale reservoirs, Reservoir symposium 2004. Schlumberger.

Lüning, S., Wendt, J., Belka, Z., Kaufmann, B., 2004. Temporal-spatial reconstruction of the early Frasnian (Late Devonian) anoxia in NW Africa: new field data from the Ahnet Basin (Algeria). SedG 163, 237-264.

Mckeon, M., 2011. Horizontal fracturing in shale plays, in: Halliburton (Ed.). Halliburton http://www.thepttc.org/workshops/eastern_062111/eastern_062111_McKeon.pdf (Accessed on 29/01/2015).

Mendelson, J., 1985. Petroleum source rock logging. Massachusets Institute of Technology, Cambridge, MA 02139.

Metwally, Y.M., Sondergeld, C.H., 2011. Measuring low permeabilities of gas-sands and shales using a pressure transmission technique. Int. J. Rock Mech. Min. Sci. 48, 1135-1144. Montgomery, S.L., Jarvie, D.M., Bowker, K.A., Pollastro, R.M., 2005. Mississippian Barnett Shale, Fort Worth basin, north-central Texas: Gas-shale play with multi-trillion cubic foot potential. AAPG Bull. 89, 155-175.

NEB, 2011. Ultimate potential for unconventional natural gas in northeastern british columbia's horn river basin. National Energy Board, http://www.nebone.gc.ca/nrg/sttstc/ntrlgs/rprt/archive/ncnvntnlntrlgshrnrvrbsnhrnrvr2011/ncnvntnlntrlgshrnr vrbsnhrnrvr2011-eng.pdf (Accessed on 10.02.2015).

Nelson, E.J., Chipperfield, S.T., Hillis, R.R., Gilbert, J.D., McGowen, J., 2007. Using geological information to optimize fracture stimulation practices in the Cooper Basin, Australia. Pet. Geosci. 13, 3-16. 
Nicolas, M.P.B., Edmonds, S.T., Chow, N., Bamburak, J.D., 2010. Shallow unconventional Cretaceous shale gas in southwestern Manitoba: an update (parts of NTS 62C, F, G, H, J, K, N). University of Manitoba, http://gov.mb.ca/iem/geo/field/roa10pdfs/GS-14.pdf (Accessed on $16 / 01 / 2015)$.

Noble, R.A., Kaldi, J.G., Atkinson, C.D., 1997. Seals, traps, and the petroleum system. Chapter 2: Oil saturation in shales: Applications in seal evaluation. American association of petroleum geologists.

O’Sullivan, F., Paltsev, S., 2012. Shale gas production: potential versus actual greenhouse gas emissions. Environ. Res. Lett. 7.

OGP, 2012. Shale gas in Europe. International Association of Oil \& Gas Producers.

Osholake, T.A., 2010. Factors affecting hydraulically fractured well performance in the marcellus shale gas reservoirs, Energy and Mineral Engineering. Pennsylvania state University, Pennsylvania, US.

Pashin, J.C., Kopaska-Merkel, D.C., Arnold, A.C., McIntyre, M.R., 2011. Geological foundation for production of natural gas from diverse shale formations. Geological survey of Alabama, Tuscaloosa, AL.

Passey, Q.R., Creaney, S., Kulla, J.B., Moretti, F.J., Stroud, J.D., 1990. A practical model for organic richness from porosity and resistivity logs. The Americal Association of Petroleum Geologists Bulletin 74, 1777 - 1794.

Pathi, V.S.M., 2008. Factors affecting the permeability of gas shales, Geological Science. The university of British Columbia, Vancouver, p. 189.

Patterson, D., 2012. AIPN EA chapter event shale gas similarities between US \& Europe, http://www.moyesco.com/Portals/0/Publications/AIPN\%20Vienna\%20May\%202012_dee.pd f (Accessed on 29/01/2015). 
Peeters, M., 2011. Review of existing shaly sand evaluation models and introduction of a new method based on dry clay parameters, SPWLA 52nd Annual Logging Symposium. Society of Petrophysicists and Well Log Analysts, Colorado Springs, Colorado, USA.

Perez, R., 2013. Brittleness estimation from seismic measurements in unconventional reservoirs: Application to the barnett shale, Conocophillips School Of Geology And Geophysics. University Of Oklahoma, Norman, Oklahoma, p. 172.

Perez, R., Marfurt, K., 2013. Calibration of brittleness to elastic rock properties via mineralogy $\operatorname{logs}$ in unconventional reservoirs, AAPG International Conference and Exhibition. American Association of Petroleum Geologists, Cartagena, Colombia.

Rajtar, J.M., 2010. Shale gas - How is it developed? XTO Energy, http://yadda.icm.edu.pl/baztech/element/bwmeta1.element.baztech-article-AGHM-0024-0031 (Accessed on 29/01/2015).

Raphael, A., 2012. Log - core calibration in unconventional reservoir, Mewbourne School Of Petroleum And Geological Engineering. University of Oklahoma, Norman, Oklahoma, p. 87. Rickman, R., Mullen, M., Petre, E., Grieser, B., Kundert, D., 2009. Petrophysics key in stimulating shales, The American Oil And Gas Reporter.

Rickman, R.M., M. ; Petre, E. ; Grieser, B. ; Kundert, D., 2008. A practical use of shale petrophysics for stimulation design optimization: All shale plays are not clones of the Barnett Shale, SPE annual technical conference and exhibition. Society of Petroleum Engineers, Denver, Colorado, USA.

Rogers, H., 2011. Shale gas - the unfolding story. Oxford Rev. Econ. Pol. 27, 117-143.

Ross, D.J.K., Marc Bustin, R., 2007. Impact of mass balance calculations on adsorption capacities in microporous shale gas reservoirs. Fuel 86, 2696-2706.

Sayers, C.M., 2013. The effect of kerogen on the elastic anisotropy of organic-rich shales. Geop 78, D65-D74. 
Schulz, H.-M., Horsfield, B., 2010. Rock matrix as reservoir: mineralogy \& diagenesis.

Shih, Y.-J., Shen, Y.-H., 2009. Swelling of sericite by LiNO3-hydrothermal treatment. Appl. Clay Sci. 43, 282-288.

Slatt, R.M., Rodriguez, N.D., 2012. Comparative sequence stratigraphy and organic geochemistry of gas shales: Commonality or coincidence? J. Nat. Gas Sci. Eng. 8, 68-84.

Stark, M., Allingham, R., Calder, J., Lennartz-Walker, T., Wai, K., Thompson, P., Zhao, S., 2012. Water and shale gas development. Accenture, USA.

Stevens, P., 2012. The ‘shale gas revolution’: Developments and changes. Chatham House. Stevens, P., 2014. Global implications of the technological revolution in the production of gas and oil. Chatham House, https://www.jccp.or.jp/international/conference/docs/prof-paulstevens.pdf (Accessed on 19/11/2014).

Stevens, P., Simons, S., De Silva, P.N.K., 2013. Shale gas in Australia: The policy options. University College London, http://www.ucl.ac.uk/australia/files/shale-gas-in-australia-greenpaper-final (Accessed on 20.01.2014).

Tang, X., Zhang, J., Wang, X., Yu, B., Ding, W., Xiong, J., Yang, Y., Wang, L., Yang, C., 2014. Shale characteristics in the southeastern Ordos Basin, China: Implications for hydrocarbon accumulation conditions and the potential of continental shales. Int. J. Coal Geol. 128-129, 32-46.

Transform, 2011. North American shale reservoirs similar, yet so different, SEG Shale Gas Technology Forum Chengdu.

Trembath, C., 2013a. Evaluating a new unconventional play in old conventional basin, FESAus Technical Meeting. Beach Energy.

Trembath, C., 2013b. Regional pressure gradients for the Cooper basin, in: Lendyn, P. (Ed.). USDOE, 2009. Modern shale gas development in the United States: A primer. United States Department of Energy, OK,73142. 
USGS, 2014. Pitkin Limestone, Fayetteville Shale (including the Wedington Sandstone member), and Batesville Sandstone (including the Hindsville Limestone Member),

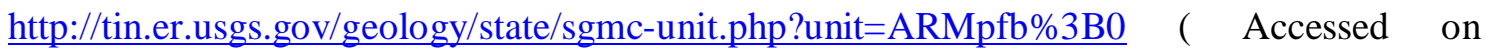
02.03.2014).

Voltolini, M., Wenk, H., Mondol, N., Bjørlykke, K., Jahren, J., 2009. Anisotropy of experimentally compressed kaolinite-illite-quartz mixtures. Geop 74, D13-D23.

Wang, G., Carr, T.R., 2012. Methodology of organic-rich shale lithofacies identification and prediction: A case study from Marcellus Shale in the Appalachian basin. Comput. Geosci. 49, 151-163.

Wang, S., Song, Z., Cao, T., Song, X., 2013. The methane sorption capacity of Paleozoic shales from the Sichuan Basin, China. Mar. Pet. Geol.

Weijermars, R., 2013. Economic appraisal of shale gas plays in Continental Europe. Applied Energy, 106, 100-115.

Yu, W., Sepehrnoori, K., 2013. Simulation of gas desorption and geomechanics effects for unconventional gas reservoirs, SPE Western Regional \& AAPG Pacific Section Meeting. Society of Petroleum Engineers, Monterey, California, USA.

Zhang, T., Ellis, G.S., Ruppel, S.C., Milliken, K., Yang, R., 2012. Effect of organic-matter type and thermal maturity on methane adsorption in shale-gas systems. OrGeo 47, 120-131.

Zhao, H., Givens, N.B., Curtis, B., 2007. Thermal maturity of the Barnett Shale determined from well-log analysis. AAPG Bull. 91, 535-549.

Zou, C., 2013. Unconventional petroleum geology. Elsevier, Boston.

Zou, C., Dong, D., Wang, S., Li, J., Li, X., Wang, Y., Li, D., Cheng, K., 2010. Geological characteristics and resource potential of shale gas in China. Pet. Explor. Dev. 37, 641-653. 